\title{
Fragmentos de la realidad social \\ posmoderna
}

\author{
Eduardo Bericat Alastuey \\ Universidad de Málaga \\ Fundación Centro de Estudios Andaluces
}

RESUMEN

En las sociedades avanzadas estamos asistiendo a tal cúmulo de transformaciones sociales, políticas, económicas y culturales que apenas puede eludirse la pregunta de si nuestras sociedades se estarán enfrentando a un verdadero «cambio de época». El presente artículo trata de responder a esta pregunta ofreciendo un amplio panorama de las principales aportaciones teóricas que diversos pensadores y científicos sociales han elaborado al observar y analizar el cambio social contemporáneo. Aunque estas aportaciones muestran la existencia de un debate entre continuistas y rupturistas, es decir, entre quienes creen que las actuales transformaciones sociales son una mera prolongación de la modernidad y quienes creen que estamos entrando en una nueva sociedad posmoderna, todos ellos insisten en la relevancia y magnitud de los cambios.

El concepto de sociedad posmoderna, cuya consolidación sociológica data de la década de los ochenta, sigue siendo un concepto polémico que adolece de la necesaria precisión y rigor. Sin duda, constituye en muchos casos un irreflexivo "concepto moda». Pero también sirve a la pretensión científica de configurar una imagen coherente de la amplísima variedad de cambios que se están produciendo en una gran multitud de ámbitos. De ahí que el artículo se configure, según la propia lógica posmoderna, como un conjunto de fragmentos de realidad social todavía carentes de la necesaria consistencia y unidad.

El artículo, por último, ofrece una visión de la sociedad emergente basada en la hipótesis de la bifurcación posmoderna. Según esta hipótesis, el proceso de posmodernización constituye el despliegue bifurcado y simultáneo de la modernidad por dos senderos, uno por el que caminamos hacia la hipermodernización y otro por el que avanzamos re-actualizando la tradición. Propone que este nuevo cambio social, el que nos lleva desde la sociedad moderna a la sociedad posmoderna, no puede entenderse desde la lógica disyuntiva y antitética con la que se comprendió el paso de la sociedad tradicional a la sociedad moderna, sino que ha de entenderse desde una nueva lógica disyuntiva y sintética, precisamente aquella con la que operan los propios procesos de posmodernización.

Palabras clave: Sociedad Postmoderna, Teoría Sociológica, Cambio Social, Cambio Cultural, Sociedad Tradicional, Sociedad Moderna. 
«Dejo a los varios porvenires (no a todos) mi jardín de senderos que se bifurcan"

Ts'ui Pên

El jardín de senderos que se bifurcan Jorge Luis Borges

\section{LA INTUICIÓN GENERALIZADA DE UN CAMBIO DE ÉPOCA}

En las sociedades avanzadas, al comienzo del tercer milenio de la era cristiana, estamos asistiendo a un cúmulo tal de transformaciones sociales, políticas, económicas y culturales que apenas podemos eludir la pregunta de si nuestras sociedades estarán entrando en una nueva época. Muchos pensadores y científicos sociales así lo consideran. Para Manuel Castells, «un nuevo mundo está tomando forma en este fin de milenio» (Castells, 1997b: 370). Según Ronald Inglehart, «durante las últimas décadas las sociedades avanzadas han traspasado un punto de inflexión y han pasado de la fase de la modernización a la fase de la posmodernización» (Inglehart, 1998: 24). En palabras de Ulrich Beck, este cambio, que tanto él como Anthony Giddens denominan «modernización reflexiva», implica «la posibilidad de una (auto)destrucción creativa de toda una época: la de la sociedad industrial» (Beck, 1994: 14). Alain Touraine presentaba La sociedad Post-industrial, publicada en 1969 , señalando que «ante nuestros ojos se están formando sociedades de un nuevo tipo» (Touraine, 1969: 5). Daniel Bell ya anticipó, en 1973, que «en los próximos treinta o cincuenta años veremos la emergencia de lo que he llamado la "sociedad post-industrial"» (Bell, 1976: 12). Por su parte, Zigmunt Bauman considera que la caída del Muro de Berlín, en 1989, cierra la época moderna inaugurada en 1789 con la Revolución Francesa, dando paso así a las realidades y al espíritu posmodernos (Bauman, 1991). Según Mike Featherstone, por último, se trata de una «ruptura con la modernidad que implica la aparición de una nueva totalidad social con sus propios y distintos principios organizativos» (Featherstone, 1988: 198).

La proliferación de nuevas denominaciones sociales expresa, del mismo modo, la intuición de una conciencia generalizada capaz de percibir este cambio de época en cualquier ámbito de la vida en el que se fije la vista y se sostenga sin prejuicios y libremente la mirada: sociedad posindustrial; sociedad posmoderna; sociedad red; sociedad de consumo; sociedad del ocio; sociedad del riesgo; sociedad de la modernización reflexiva; sociedad tardomoderna; sociedad de la información; sociedad de la comunicación; sociedad del conocimiento, y otras tantas nuevas definiciones que pudieran citarse. El reto sociológico ante el que nos enfrentamos estriba en pasar desde una conciencia de posmodernidad intuida a una conciencia que perciba con claridad la dinámica del cambio y su probable destino final. 
El reto político viene condicionado por la necesidad de establecer metas adecuadas al cambio de época e intervenir con el objeto de que las transformaciones futuras se adapten a los deseos y a la justa medida de los seres humanos.

Sin embargo, del mismo modo que Simmel sólo ofreció en su obra fragmentos de la realidad moderna, creemos que en la actualidad tan sólo estamos en disposición de ofrecer algunos fragmentos de la realidad social posmoderna. Los epígrafes de este artículo contienen algunos de esos fragmentos sobre los que parece existir, al menos, una evidencia científico-social razonable. Aunque la variedad de fenómenos aludidos es muy amplia, todos ellos son elementos fundamentales y definitorios del cambio social al que nos estamos enfrentando: percepciones artísticas, sensibilidades religiosas, descubrimiento y aplicación de nuevas tecnologías, concepciones científicas, valores culturales, estructuras de interacción, instituciones políticas, sistemas productivos, identidades comunitarias, etc. Tal es la cantidad de procesos de cambio emergentes, y trascendentales tanto para la vida de los individuos como para las sociedades constituidas por éstos, que una apresurada o prematura sistematización de los mismos bloquearía de raíz nuestra capacidad y sensibilidad para percibir lo que de radicalmente nuevo adviene con este cambio de época, esto es, aquello que aparece ya anunciado pero que todavía no se muestra con meridiana claridad.

El observador de este cambio de época, por tanto, hará bien en resistir el atractivo canto de las sirenas que siempre emana de la coherencia, muchas veces tan sólo aparente, cuando no falsa, de toda síntesis de pensamiento social. Hoy necesitamos ante todo mantener los ojos bien abiertos para descubrir los nuevos meandros que canalizarán en el futuro el curso de la vida social, y necesitamos afinar nuestro oído para ser capaces de escuchar el lejano y leve rumor de este pequeño río, al que podemos convencionalmente denominar posmodernidad, y que a buen seguro mañana o pasado mañana se convertirá en un inmenso mar. Pese a todo lo dicho, nos hemos atrevido a incluir en el último epígrafe una hipótesis general acerca del cambio social posmoderno, una hipótesis que, de estar empíricamente contrastada, denominaríamos teoría de la bifurcación posmoderna. En todos los epígrafes de este artículo, que pueden y deben leerse como unidades autónomas que refieren específicos procesos de cambio, podrá percibirse siempre el eco de un doble curso que parece seguir el río de la posmodernidad. Por un lado, en cada uno de los aspectos tratados en estos epígrafes puede observarse que la posmodernidad avanza siempre en el sentido de un mayor grado de modernización, esto es, en el sentido de una hipermodernizacion. Por otro lado, también en cada uno de estos aspectos podrá observarse un avance orientado a recuperar valores, recursos y estructuras típicos de las sociedades tradicionales, esto es, procesos de tradicionalización. Éste es, en síntesis, el contenido observacional de la hipótesis de la bifurcación posmoderna. El individuo posmoderno demanda más modernidad y, al mismo tiempo, más tradición. 


\section{BREVE HISTORIA DEL CONCEPTO DE POSMODERNIDAD}

Perry Anderson, en su obra titulada Los orígenes de la posmodernidad, nos ofrece un panorama histórico-intelectual de la aparición de este término, así como de las ideas y contextos a él asociados. Curiosamente, aparece por primera vez en letra impresa en la Antología de la poesía española e hispanoamericana (1882-1932) de Federico de Onís, publicada en 1934. Posteriormente, reaparece en el octavo volumen de A Study of History, publicado en 1954 por Arnold Toynbee. Para Toynbee, el industrialismo y el nacionalismo constituían las fuerzas motrices de la civilización occidental. Sin embargo, ambas estaban en contradicción, puesto que el industrialismo pugnaba naturalmente por una expansión de mercados que trascendía las fronteras nacionales. A su vez, el nacionalismo tendía a difundirse por contagio ideológico hacia ámbitos étnica o territorialmente más reducidos, socavando las identidades nacionales. Por último, la civilización occidental estaba ligada a la existencia de la burguesía, pero esta clase, en la «edad post-moderna», estaba amenazada tanto por la emergencia de una potente clase obrera industrial como por el surgimiento de burguesías no occidentales que pugnaban por la modernización de sus respectivos países. Sin embargo, el gran peligro estribaba en la propia indolencia de la clase burguesa occidental, que, hacia finales del siglo xIx, creía haber llegado a un Fin de la Historia en el que la prosperidad alcanzada se mantendría por sí misma. Las dos guerras mundiales del siglo xx, así como la amenaza nuclear, hicieron que Toynbee se cuestionara incluso el mismo concepto de «civilización» que había inspirado toda su obra. La tecnología nos enfrentaba al horror de la destrucción total, y solamente una autoridad política global y una nueva religión universal, en opinión de Toynbee, podrían salvarnos del desastre.

Hacia finales de los años cincuenta, el sociólogo C. Wright Mills, en su célebre obra titulada La imaginación sociológica (1959), presentó también una sombría visión de la posmodernidad, una edad en la que los ideales modernos del liberalismo y del socialismo estaban a punto de derrumbarse, mientras que la razón y la libertad se iban separando en una sociedad posmoderna de ciega fluctuación y vacua conformidad. El sociólogo Amitai Etzioni también aludió en La sociedad activa (1968) a un período «post-moderno», concebido en este caso como un horizonte optimista en el que el declive del poder de las grandes empresas y de las élites establecidas auguraba la posibilidad de una democracia auténtica. Este optimismo era compartido por el poeta Charles Olson, quien, en una carta de 1951 dirigida a su amigo Robert Creeley, refería un «mundo post-moderno» más allá de la revolución industrial. Olson conjugaba en su obra una visión amable de los automóviles y de la cibernética y una intensa atracción por las culturas antiguas.

En 1972 apareció en Binghamtom la revista boundary 2, subtitulada Journal of Posmodern Literature and Culture. Entre su primeros colaboradores se encontraba Ihab Hassan, un 
crítico que acababa de publicar su primer ensayo sobre posmodernidad. Incluía como posmodernas un amplio conjunto de tendencias artísticas que bien habían radicalizado, bien habían rechazado los rasgos dominantes de la modernidad. Entre éstos se encontraban John Cage, Robert Rauschenberg y Buckminster Fuller. Hassan asoció con la posmodernidad la noción de ruptura epistémica de Foucault, el juego de la indeterminación vinculado al principio de incertidumbre de Heisenberg, así como muchos motivos del pensamiento posestructuralista. Criticaba a los marxistas por su determinismo social y por su desconfianza hacia el placer estético, y se adhería a la tolerancia y al espíritu optativo del pragmatismo americano, siguiendo el pensamiento del filósofo William James. Sin embargo, los análisis de Hassan estaban más centrados en lo que De Onís había denominado «ultramodernismo", así que cuando observó en los ochenta la deriva artística "posmodernista», muy evidente en Warhol, comenzó a pensar que todo aquello no era sino un conjunto de bufonadas eclécticas y futiles, atrapadas en su propia estética kitsch, y dominadas por la burla y la parodia.

Lo posmoderno en arte alcanzó un impacto público mucho mayor al consolidarse esta tendencia en arquitectura. Robert Venturi y sus colaboradores publicaron en 1972 Learning from Las Vegas, el manifiesto arquitectónico de la década en el que lanzaron un ataque iconoclasta contra la arquitectura moderna. Según ellos, la arquitectura debía retornar a la primacía del símbolo sobre el espacio. «Las Vegas», más allá del juicio social y moral que suscitara, exigía un análisis formal de su alegre caos de signos. «Contrastando la monotonía planificada de las megaestructuras modernas con el vigor y la heterogeneidad del espontáneo desparramamiento urbano, Learning from Las Vegas resumía la dicotomía entre ambas en una frase: “Construir para el Hombre" frente a "construir para hombres (mercado)"» (Anderson, 2000: 34). Pero fue el crítico Charles Jencks quien dio el nombre posmoderno a esta corriente al publicar, en 1977, Language of Postmodern Architecture. Los preceptos básicos de esta arquitectura incluían la variedad, la legibilidad popular y la simpatía contextual, lo que podía interpretarse como un eclecticismo radical o un «tradicionalesco» visible, por ejemplo, en la obra de Gaudí.

Charles Jencks formalizó posteriormente la idea arquitectónica posmoderna teorizando su eclecticismo como una "doble codificación». La arquitectura posmoderna resultaba ser un híbrido de sintaxis «moderna» e «historicista», que apelaba tanto al gusto refinado como a la sensibilidad popular; mezcla de lo nuevo y lo viejo, de lo alto y de lo bajo. La aportación más significativa de Jencks fue «distinguir tempranamente entre arquitectura "moderna tardía" y "posmoderna" ». Abandonando la tesis de que la arquitectura moderna se había derrumbado a principios de los años setenta, Jencks admitió que su dinámica aún sobrevivía, aunque de forma paroxística, como una estética de la destreza tecnológica cada vez más desligada de todo pretexto funcional, pero todavía inasequible al juego de la alusión y la re- 
trospectiva que caracterizaba a la posmodernidad» (Anderson, 2000: 36). La utilización plural y sin cortapisas de los recursos simbólicos respondía, según el crítico, a la necesidad contemporánea de una nueva espiritualidad, similar a la que se suscitó en el exuberante barroco. La tolerancia plural y la libertad de elección se imponen en una sociedad de la información configurada por una red electrónica global, sin centro definido, que conecta a individuos de todo el mundo compitiendo y creando sentido, un sentido inserto en un orden simbólico compartido similar al tipo que ofrecen las religiones.

Alain Touraine, en La sociedad post-industrial (1969), intuyó cambios clave desde una «sociedad de industrialización capitalista» hacia una «sociedad programada», posindustrial o tecnocrática. Intuyó la nueva funcionalidad del conocimiento en los sistemas de producción; el declive del papel de la clase obrera tradicional; la importancia de los movimientos sociales emergentes, como el movimiento estudiantil de mayo del 68; la aparición de nuevas formas de dominación social, orientadas hacia la manipulación de las conciencias; la importancia del consumo, incluso en su formas masificadas; así como la relevancia de las revoluciones culturales en las nuevas formas de contestación social, que no podían ser ya exclusivamente económicas. Con El advenimiento de la sociedad post-industrial (Bell, 1973) surgió el primer intento riguroso de prognosis social que tomaba en cuenta algunos factores determinantes de cambio que trascendían la lógica de la sociedad industrial. Partiendo de un cambio en la estructura ocupacional, en la que los trabajadores del sector servicios pasaban a ser más de la mitad de la población ocupada total, Bell sostuvo que el conocimiento se convertiría en el principio axial de la nueva sociedad, y los profesionales, técnicos y expertos de la información en sus clases sociales hegemónicas.

La posmodernidad, por último, apareció en la filosofía de la mano de Jean-François Lyotard, con la publicación en 1979 de La condición posmoderna, un informe sobre el estado del conocimiento contemporáneo que el gobierno de Quebec había encargado al filósofo. Un año más tarde, Jürgen Habermas pronunció en Frankfurt un discurso titulado La modernidad, un proyecto inacabado, en el que defendió sin fisuras la vigencia de los valores modernos contra la ideología antimoderna de los jóvenes conservadores, contra la ideología premodernista de algunos conservadores viejos y contra la ideología posmodernista de los neoconservadores. Aunque el discurso de Habermas no fue una respuesta, tal y como habitualmente se cree, al trabajo de Lyotard, que no conocía, sino a la exposición de la Bienal de Venecia de 1980, en la que se mostró una buena gama de producción artística posmoderna, la supuesta «polémica» entre ambos filósofos puede considerarse como el momento en que el término «posmodernidad» adquiere un estatuto insoslayable y de alcance universal en el arte, en las ciencias humanas y en las ciencias sociales. El concepto de posmodernidad se consolida, por tanto, hace ya algo más de dos décadas. 


\section{LA POSMODERNIDAD EN EL ARTE}

Algunos autores, como Featherstone (Featherstone, 1991), distinguen entre posmodernismo, posmodernidad y posmodernización. Los estudiosos del posmodernismo analizan el contenido de unas nuevas tendencias artísticas y culturales opuestas a la producción artística y cultural propia del modernismo. Los de la posmodernidad centran sus análisis en el cambio de un orden social completo, análisis con una orientación similar al que desarrollaron los sociólogos clásicos al contrastar la sociedad moderna con la sociedad tradicional o premoderna que la precedió. Los de la posmodernización, por último, en el marco de una sociología del desarrollo, observarían más directamente las consecuencias de los nuevos cambios económicos y tecnológicos sobre la cultura y la sociedad. En este tercer fragmento se exponen algunos de los rasgos de las corrientes artísticas y culturales posmodernas destacados por Frederic Jameson, un crítico literario marxista que en 1982 pronunció sobre el tema una conferencia titulada The Cultural Turn, y que en 1991 publicó su gran obra, Posmodernism, or, the Cultural Logic of Late Capitalism. Jameson establece un paralelo entre las fases del capitalismo establecidas por Ernest Mandel y diversas corrientes culturales. Así, al «capitalismo de mercado» le correspondería un realismo cultural; al capitalismo monopolista o imperial, una cultura modernista, y al capitalismo multinacional, tardío o de consumo, una cultura posmodernista. El posmodernismo no es, según Jameson, un mero estilo artístico, sino la lógica cultural correspondiente al capitalismo tardío. Sin embargo, el interés de la obra de Jameson estriba en sus análisis artísticos y culturales, de los que expondremos dos célebres ejemplos paradigmáticos. Uno en el que compara los cuadros Un par de botas, de Vincent van Gogh, y El grito, de Edward Munch, con un cuadro de Andy Wharhol, Zapatos de polvo de diamante; y otro en el que analiza un edificio puramente posmoderno, el hotel Westin Bonaventure que John Portman construyó en el centro de Los Ángeles.

El par de botas de Van Gogh es un par de botas de campesino, y aquí los objetos representados nos trasladan más allá del cuadro hacia un mundo misérrimo de vida agrícola y rural con agotadoras jornadas de trabajo. Expresa el sudor y el sacrificio humano, al mismo tiempo que la dignidad de todo hombre. En la interpretación que hace Heidegger en El origen de la obra de arte, destaca la capacidad del arte para superar el abismo entre la Tierra y el Mundo, esto es, entre la pura materialidad de los objetos y el sentido histórico y social de los mismos. Los objetos, por tanto, refieren el contexto vital en el que se hallan inscritos. El objeto, en la obra de arte, nos habla del propio ser del objeto, de su verdadero sentido. Las botas se constituyen así como síntomas de una realidad mayor y trascendente.

Los zapatos de Warhol, en opinión de Jameson, ya no nos hablan, no nos hablan de nada en absoluto; se presentan como pura contingencia, como fetiches de escaparate. Este cua- 
dro, una representación fotográfica en negativo de unos zapatos de señora «que cuelgan del lienzo como un haz de nabos» (Jameson, 1998: 31), carece de contexto vital de referencia. No hay modo de recuperar en ellos la sala de baile, el mundo de la moda o de la jet set o de las revistas del corazón. En la mercantilización presente en la obra de Warhol, de forma notoria en sus lienzos de Coca-Cola o en los de sopa Campbell, se pone en evidencia el fetichismo de la mercancía propio del capitalismo tardío. Un tercer rasgo que se destaca es la ausencia de profundidad, la superficialidad, «quizás el supremo rasgo formal de todas las posmodernidades» (Jameson, 1998: 31). El cuarto rasgo sería la ausencia de afectos en la cultura posmoderna, ausencia que expresa tanto la frivolidad existencial de los objetos como la de los mismos sujetos. Marilyn Monroe mercantilizada y transformada en sus propias imágenes. En el arte moderno, como en la obra El grito, de Munch, el sujeto siente angustia, siente con intensidad las condiciones de su existencia, su alienación y su soledad. Existe una emoción interior que se proyecta hacia fuera. Pero nada de esto aparece en el arte posmoderno, que rechaza las diferencias entre esencia y apariencia, latente y manifiesto, auténtico e inauténtico, significante y significado. «Sustituye la profundidad por la superifice o por múltiples superficies» (Jameson, 1998: 34). La subjetividad desaparece, el sujeto desaparece, y las emociones angustiosas y alienantes de la modernidad desaparecen. El sujeto muere, se diluye, se descentra y se fragmenta. En el contraste también se observa, por último, el declive de las grandes temáticas modernistas del tiempo y la temporalidad, de la durée y de la memoria. En la posmoderidad prevalece lo sincrónico sobre lo diacrónico, el espacio predomina sobre el tiempo y la historicidad. Eternos presentes instantáneos.

El hotel Westin Bonaventure constituye un ejemplo de mutación posmoderna del espacio construido, una mutación que todavía no podemos percibir y a la que no estamos adaptados. Frente al espacio antiguo del modernismo, surge el hiperespacio del posmodernismo. Según la filosofía de otros arquitectos posmodernos (Robert Venturi, Charles Moore, Michael Graves y Frank Gehry), las obras tienen que ser populares, esto es, gustar a la gente, y de hecho el hotel es uno de los edificios más visitados de Los Ángeles. Además, debe respetar el tejido urbano, pues no se trata, como en la arquitectura moderna, de crear un espacio utópico distinto, sino de trabajar con su mismo léxico y sintaxis. De hecho, el hotel tiene tres entradas, pero no hay ninguna gran entrada con marquesina, como en los hoteles modernos, que resalte la diferencia entre los espacios interior y exterior. El interior del hotel pretende ser un espacio total, una especie de ciudad en miniatura, dispuesto para que los seres se muevan y se reúnan de un modo especial. El hotel no pretende, por tanto, segregarse de la ciudad degradada y decadente, sino más bien representarla. La piel de cristal que cubre el exterior del edificio no muestra el hotel, sino que, mediante sus reflejos, representa el tejido urbano que existe en el entorno. 
Un aspecto a destacar es la importancia concedida a escaleras y ascensores, esos transportadores de gente, en palabras de Portman, que plantean «nuestras trayectorias físicas por estos edificios en términos de narrativas o historias virtuales» (Jameson, 1998: 60). El movimiento adquiere un sentido peculiar porque el trayecto se convierte en narración del ser que existe en este hiperespacio. El hiperespacio sólo puede ser recorrido, pero nunca cartografiado. Aspecto capital que se destaca en la configuración de un vestíbulo en el que los banderines colgantes nos impiden ver su volumen total, la forma espacial de ese vacío construido. Carecemos de la suficiente perspectiva y profundidad para ver el espacio; sólo divisamos gentes recorriendo su respectivas trayectorias. El ascensor nos dispara a través del techo por una de la cuatro columnas del vestíbulo, y se muestra la ciudad en imágenes, Los Ángeles como espectáculo. Bajamos de nuevo al vestíbulo y, «dada la absoluta simetría de las cuatro torres, es casi imposible orientarse» (Jameson, 1998: 62). En este hiperespacio posmoderno destaca la incapacidad para cartografiar cognitivamente el espacio y nuestra posición, metáfora de «la incapacidad de nuestras mentes, al menos hoy por hoy, de cartografiar la gran red global comunicacional, multinacional y descentrada en la que, como sujetos individuales, nos hallamos atrapados» (Jameson, 1998: 62). Es una realidad sólo captada en y por el movimiento.

Nueva superficialidad, que afecta tanto a la teoría y a la imagen como a los múltiples simulacros; debilitamiento del sentido histórico de la existencia; ocaso de los afectos de angustia y de alienación y, en general, de todos los afectos salvo la euforia; muerte, fragmentación o descentramiento del sujeto; omnipresencia del pastiche como forma posmoderna de parodia sin referente original; cultura del simulacro; arte de la composición en collage; prevalencia de la nostalgia y de las modas «retro»; dominio de los significantes y crisis general de la representación; hiperespacios de trayectorias móviles; evasiones eufóricas; mercantilización de la cultura; de-diferenciación entre cultura de élites y cultura de masas; privilegio de lo visual, transformación de la realidad en imágenes; de-diferenciación de las esferas culturales; fragmentación del tiempo en instantes presentes perpetuos. Heterogeneidad, fragmentación, aleatoriedad. Éstos son algunos de los rasgos que Jameson atribuye a la cultura posmodernista, lógica de una fase del capitalismo en la que lo cultural adquiere una hegemonía sobre los restantes dominios de la existencia individual y social. No hay hecho social, económico, político o existencial que no esté orientado esencialmente por la dinámica de los símbolos. Pero esta dinámica se configura según una textualidad esquizofrénica, en la que el sentido se constituye no mediante la unión orgánica y lingüística de los significantes de un enunciado, sino mediante un amasijo de significantes distintos y sin relación (Jameson, 1998: 47). La ruptura de la cadena de significantes aporta carga emocional al momento vivido, al que sigue aleatoriamente otro momento, otra imagen, otro sonido, otra palabra; en suma, otro significante aislado, para conformar un conjunto de presentes disyuntivos con los que ha de construirse la identidad. El zapping y el collage 
son tan sólo la expresión superficial y empobrecida de esta lógica cultural y simbólica posmoderna.

\section{SOCIEDADES TRADICIONALES, MODERNAS Y POSMODERNAS}

Para comprender la posmodernidad se requiere una amplia visión histórica que incluya la simultánea consideración y entendimiento de tres tipos sucesivos de sociedad: la «tradicional», la «moderna» y la «posmoderna». Esto es así porque la modernidad, contemplada desde la perspectiva de la tradición, presenta ante nuestros ojos una imagen completamente distinta de la que percibimos desde el horizonte de la posmodernidad. Esta afirmación no implica que existan dos «modernidades», pero sí que la naturaleza de las cosas, y de las sociedades, sólo se revela en su totalidad al pensamiento en la múltiple comparación con otras cosas. Cada contraste resalta una constelación particular de rasgos característicos de la sociedad moderna, por lo que solamente desde la ambivalencia que revela esta mirada dual de la modernidad puede emerger una conciencia clara de la posmodernidad. Éste es el motivo por el que nos parece muy adecuada la consideración simultánea tanto de los logros y los costes como de los gozos y los malestares de la sociedad moderna, aspecto muy bien tratado en la obra de David Lyon Posmodernidad. Ésta es la razón por la que es preciso volver a los sociólogos clásicos, cuyo único y fundamental empeño fue comprender la sociedad moderna, mirando al futuro, desde el horizonte de la sociedad tradicional.

Los sociólogos clásicos destacaron tres procesos fundamentales de la sociedad moderna: la racionalización, la mercantilización y la diferenciación. Max Weber destacó que la modernización estaba alentada por una racionalidad específica, una racionalidad instrumental que vinculaba medios y fines, sin necesidad de que los fines estuviesen justificados. El proceso de racionalización no era, para Weber, una cuestión mental, sino institucional, dado que todas las instituciones de la modernidad, desde las económicas hasta las políticas, se organizaban con esta racionalidad operativa justificada por la eficiencia. La razón ilustrada pretendía ordenar el mundo desde el saber objetivo procurado por el conocimiento científico. El mundo natural, social y personal eran cognoscibles, y en la conjunción de saber y hacer, de ciencia y tecnología, la modernidad prometeica auguraba un futuro de luz y progreso en contraste con la miseria económica, intelectual y moral de las sociedades premodernas. Sabido es que Weber no compartía el optimismo ilustrado, pues sintió desde el principio que la racionalidad instrumental, llevada hasta el extremo, tendría dos graves consecuencias. Una de ellas la «burocratización» del mundo, que tejería una jaula de hierro en la que los individuos nos veríamos atrapados por los imperativos de racionalidad instrumental y eficiencia de unas macroorganizaciones formales, rígidas y opresivas que serí- 
amos incapaces de dominar. La segunda se refiere al «desencantamiento» del mundo, que llegaría con la racionalización total de la vida. La razón instrumental diluye la razón sustantiva sobre la que se funda todo sentido humano, por lo que su avance podría traernos bienestar material, pero pondría en riesgo todo sistema de creencias más allá del mero conocimiento objetivo.

La obra de Karl Marx tuvo por objeto el análisis económico y social del modo de producción capitalista. El capitalismo, como modo de producción capaz de liberar las fuerzas productivas y configurar un sistema de actividad revolucionario que modifica radicalmente las relaciones del hombre con la naturaleza, por medio del trabajo y la tecnología, nunca es cuestionado en la obra de Marx. Lo cuestionable, sin embargo, son las relaciones de producción que se establecen bajo el principio de la propiedad privada y las formas capitalistas de apropiación de la plusvalía. El futuro de provisión material tan sólo se traslada a una sociedad sin clases gobernada por los principios de la necesidad y de la capacidad de cada hombre. La épica de la energía, del maquinismo, de la ciencia y de la tecnología no desaparece en la sociedad futura. Pero sí desaparecen la alienación y la explotación inscritas en la total mercantilización de la vida gobernada por la lógica de la acumulación de capital. Alienación de los sujetos, obreros y capitalistas, subsumidos ambos en la dinámica capitalista, incapaces de dominar el sistema. Explotación de los obreros, a quienes los capitalistas hurtan la contraprestación natural de su trabajo y esfuerzo. Mercantilización de la vida, en la que los valores de uso desaparecen bajo la égida de los valores de cambio. Todo, incluso el propio ser humano, se convierte en mercancía, acaba fetichizado en la forma de mercancía.

Para Durkheim, el rasgo básico que caracteriza a la sociedad moderna es la creciente diferenciación de sus estructuras tanto sociales como culturales. Este proceso de diferenciación tiene una de sus claves en la división social del trabajo y de la actividad económica en unas funciones cada vez más específicas. El trabajo se especializa en ocupaciones y profesiones más concretas y definidas; las empresas se orientan hacia producciones cada vez más singulares; el trabajo se segrega del hogar; se separan la economía, la cultura, la sociedad y la política; y se especializan las ciencias desde el tronco común de la filosofía. La sociedad moderna se convierte en una estructura orgánica que une lo diferente, precisamente por ser diferente, esto es, por complementación. Estaremos menos unidos, parece decirnos Durkheim, pero nos necesitaremos más, pues en un mundo diferenciado el individuo autónomo resulta ser un imposible. Un paso de la «solidaridad mecánica», en la que los individuos están fusionados comunicativamente en la comunidad, a la «solidaridad orgánica», una solidaridad externa basada fundamentalmente en mónadas individuales y aisladas con relaciones contractuales de intercambio necesario. Una sociedad generadora de individualismo y anomia que Durkheim observó con cierto pesar en su análisis del suici- 
dio (Bericat, 2001), en el que se reflejaba la existencia de un malestar general producido por el excesivo aislamiento individual, así como por el perpetuo estado de anomia y de frustración característico de las sociedades de cambio y de las sociedades orientadas más hacia la incesante búsqueda de hipotéticos logros futuros, que hacia el tranquilo disfrute de lo ya conseguido y disponible en el tiempo presente.

La ambivalencia de la modernidad, como hemos visto, estaba muy presente en la obra de los sociólogos clásicos y, junto al reconocimiento de sus grandes e indudables logros económicos, tecnológicos, políticos y culturales, encontramos la consideración explícita de algunas importantes consecuencias indeseables que, con el transcurso del tiempo, están conformando una nueva mentalidad posmoderna que se enfrenta desde la modernidad a los costes de la modernidad. En este sentido, todos ellos anuncian la posmodernidad, aunque tan sólo otro sociólogo clásico, George Simmel, puede ser calificado, en opinión de G. Stauth y B. Turner, como el primer sociólogo de la posmodernidad. Entre otros motivos, por el interés central que otorgó en sus análisis a la cultura, por la forma asistemática y fragmentaria con la que trató de captar las existencias modernas, y por la revelación de la dialéctica entre las formas objetivas y fijas en las que la vida tiene necesariamente que expresarse, y la fuerza de la vida que siempre palpita bajo esas formas. Esta lucha entre la «forma» y la «vida» está presente, más que nunca, en el espíritu de la naciente cultura y sociedad posmodernas. En El conflicto de la cultura moderna (Simmel, 1997), Simmel señala que existe un perpetuo dinamismo por el que la vida, en constante evolución y movilidad, erosiona cualquier forma cultural, que por otra parte ella misma ha creado, cuando la forma se objetiva e institucionaliza, se hace rígida e inflexible y pretende anular su vitalidad. En estas situaciones emerge un difuso pero profundo malestar cultural que alimenta la tensión creativa de la vida orientada al alumbramiento de nuevas formas.

Simmel ejemplifica esta lucha en tres corrientes culturales, el expresionismo artístico, el pragmatismo filosófico y el misticismo religioso. Tres corrientes en las que puede observarse la negación absoluta de un posicionamiento epistemológico típicamente moderno que separa radicalmente al sujeto del objeto, que enfrenta, desde una profunda diferenciación, subjetividad y objetividad.

En franco contraste con la pintura que pretende representar objetivamente la realidad exterior, es decir, representar al objeto tal y como es, el expresionismo pretende representar la subjetividad del artista, su propio impulso en el trabajo de creación. No existe ni tiene por qué existir parecido morfológico entre el objeto y su representación, porque el objeto es asimilado subjetivamente por la vivencia del artista, y el cuadro ha de expresar, en un acto de voluntad creativa, el sentido que para el artista tiene ese preciso objeto en esa precisa ocasión. El gran atractivo popular del Van Gogh expresionista reside en su intensa pasión 
estética, en la absoluta espontaneidad de su hacer creativo, así como en la autenticidad vital que transmite en el profundo deseo de expresarse a sí mismo.

En el pragmatismo filosófico encontramos de nuevo la negación de la forma objetiva, la negación del conocimiento objetivo que es sustento de la modernidad. El pragmatismo no acepta que exista algo así como una verdad objetiva que pueda obtenerse mediante la aplicación de un conjunto de reglas formales, tal y como lo hace la ciencia. Para esta corriente filosófica, el criterio de verdad se fundamenta en una conexión vital entre las ideas, o conocimientos, y las consecuencias que estas ideas, o conocimientos, tengan para la propia vida del hombre. El conocimiento no es independiente de la vida, pues sólo la vida es capaz de comprenderse a sí misma.

En el ámbito de la vida religiosa, por último, Simmel contrapone las formas institucionalizadas y objetivas en las que la religiosidad ha de expresarse en cada sociedad concreta a la espiritualidad inmanente que yace en el interior del corazón humano. Observa que un número bastante grande de personas intelectualmente progresistas encuentran en el misticismo la satisfacción de sus necesidades religiosas. La actual institucionalización religiosa no canaliza adecuadamente los anhelos de religiosidad ni las aspiraciones espirituales del alma. «Uno de los más profundos dilemas espirituales que afectan a innumerables hombres modernos se basa en que, si bien es imposible preservar durante más tiempo las iglesias religiosas tradicionales, el impulso religioso todavía pervive. Ninguna cantidad de "ilustración" puede destruirlo, sólo podrá robarle su vestimenta exterior, pero no su vida» (Simmel, 1977: 89). La posmodernidad vuelve a fundir lo que la modernidad había separado, vuelve a la subjetividad, a la autenticidad, a la emoción. Desde las sordas pulsiones vitales pretende recrear nuevas formas de existencia y de sociabilidad.

\section{EL PODER DE LAS REDES Y EL PODER DE LA IDENTIDAD}

Pese a que en ningún momento utiliza el término posmodernidad, en la gran obra de Manuel Castells, La era de la información, están presentes muchos de los rasgos que otros autores atribuyen a la sociedad posmoderna. En el marco de una consideración más estructural de la nueva sociedad, denominada «sociedad red», se estudian los cambios acontecidos en la producción, en el poder, en la cultura, en las relaciones sociales y en los modos de existencia. Según este sociólogo, el nuevo mundo en formación surge por la coincidencia histórica de tres procesos independientes: la revolución de las tecnologías de la información y de la comunicación; la crisis económica tanto del capitalismo como del estatismo, y el florecimiento de nuevos movimientos sociales. Estos procesos han generado una nueva estructura social dominante, la sociedad red; una nueva economía, la economía 
informacional/global; y una nueva cultura, la cultura de la virtualidad real (Castells, 1997b: 371). Las tecnologías de la información y de la comunicación constituyen la base material de esta nueva sociedad, y contienen los tres elementos clave que sustentan el resto de transformaciones: a) conocimiento; b) movilidad, y c) red. Pueden analizarse por separado, pero es su íntima conexión la que les otorga el poder catalizador para revolucionar todos y cada uno de las ámbitos de la vida que podamos imaginar. Es la conexión entre ordenadores, que operan a gran velocidad con gran cantidad de información, y redes, capaces de transportar al instante gran cantidad de información, lo que establece un cambio radical en las esferas del conocimiento, generando una macroestructura cerebral compuesta por la inmensa trama de «ordenadores-en-red» (Bericat, 1996) que almacenan, operan y comunican la fabulosa cantidad de información actualmente disponible.

Comprendemos el segundo elemento clave al comparar la «movilidad biológica», de la sociedad tradicional, y la «movilidad mecánica», de la sociedad moderna, con la movilidad electrónica de la «sociedad posmoderna». La diferencia básica estriba en que las primeras son capaces de transportar macromateria, es decir, objetos, a una velocidad limitada, mientras que la tercera es capaz de trasladar micromateria, susceptible de ser codificada y descodificada en símbolos, a la velocidad de la luz. A partir de aquí, la lógica de la movilidad electrónica se impone sobre la estructuración del espacio territorial de las sociedades tradicional y moderna. Observando este proceso se pone en evidencia el hecho de que un nuevo tipo de movilidad siempre acaba configurando un nuevo tipo de espacio y una nueva forma del tiempo. Sucedió con la incorporación del automóvil, y sucederá con la de las redes telemáticas (Bericat, 1994). En palabras de Castells, las estructuras sociales se concentran en el «espacio de flujos», típico de la era de la información, conformado por una red electrónica global, y se fragmentan en un «espacio de los lugares», con base territorial, típico de las eras precedentes. Del mismo modo puede observarse una dualidad similar entre el «tiempo intemporal», un tiempo que se deshistoriza, de instantes aleatorios, efímeros y de virtualidad real, propio de la movilidad financiera y audiovisual, y un «tiempo de reloj» al que seguirán sometidas las actividades fuera de la red.

La forma «red», por último, determina una lógica de enlace radicalmente diferente a las empleadas en las formas organizativas de la modernidad, es decir, a la forma «mercado», en la que las unidades o individuos gozan de autonomía y la relación se funda en la suscripción de contratos entre las partes, y a la forma «burocracia», que implica una unidad orgánica planificada formalmente en la que las partes tienen funciones especializadas y establecidas a priori. La red constituye una lógica híbrida de enlace, de nodos conectados por "vínculos débiles», que permite construir megaestructuras globales con gran capacidad de adaptación. Una lógica organizativa especialmente apta para una época de cambios rápidos y profundos, una época en la que la innovación y la flexibilidad determinan la 
supervivencia, y una época en la que se tejen estructuras con una potente centralización a escala global, pero basadas en una múltiple fragmentación a escala local. Desde las empresas a los Estados, pasando por los movimientos sociales y las relaciones individuales, se están reorganizando en red.

Para Castells, «esta evolución hacia las formas de gestión y producción en red no implica la desaparición del capitalismo». «Es más, por primera vez en la historia, el modo de producción capitalista determina la relación social de todo el planeta» (Castells, 1996: 507). Pero Castells entiende que se trata de un capitalismo profundamente diferente de sus predecesores, cuyos rasgos distintivos son que es «global» y que se estructura en torno a una «red de flujos financieros». Estamos ante un nuevo «capitalismo informacional global», gobernado por la dinámica de una red de flujos financieros, una especie de «casino global», en el contexto de una geometría variable y difusa, que constituye el sistema nervioso de este capitalismo y dirige los grandes movimientos estratégicos de su sistema económico. La dualidad aparece de nuevo, pues el capital es global, abstracto y colectivo, mientras que el trabajo es local, concreto e individualizado. La división en clases de la sociedad red se establece, en primer término, en el marco de la diferencia entre el mercado de las redes de capital y la vida de los trabajadores; en segundo término, entre los trabajadores «autoprogramables», muy productivos y capaces de aportar cualificación a la red, y los «trabajadores genéricos", sin cualificación y de baja productividad; $y$, en tercer término, por la clase de los excluidos, aquellos individuos prescindibles para el sistema como trabajadores y como consumidores.

Las fases tradicional, moderna y posmoderna también se aplican a la experiencia humana, sobre todo en cuanto afectan a los tipos de vínculo entre cultura y naturaleza. En la primera el hombre y su cultura están dominados por la naturaleza; en la sociedad industrial la cultura del hombre domina sobre la naturaleza, y en la tercera «entramos en un estadio en que la cultura hace referencia directa a la cultura». En esta tercera fase, por ejemplo, el movimiento ecologista pretende «reconstruir la naturaleza como una forma cultural ideal». «Hemos entrado en un modelo puramente cultural de interacción y organización sociales». «Es el comienzo de una nueva existencia y, en efecto, de una nueva era, la de la información, marcada por la autonomía de la cultura frente a las bases materiales de nuestra existencia» (Castells, 1996: 513-514). Si la producción está dominada por los flujos financieros, la cultura está dominada por las «redes electrónicas de comunicación», que conforman mediante un «hipertexto audiovisual digitalizado» una eficiente «virtualidad real».

En este contexto, en el que asistimos a la crisis del Estado-nación, de la democracia política y del Estado de Bienestar, en el que la localización del poder es difusa, en el que el mo- 
vimiento obrero, las iglesias mayoritarias y las ideologías políticas pierden relevancia, en el que existe una distancia abismal y alienante entre las redes globales y las existencias individuales, se están configurando unas nuevas «identidades de resistencia», organizadas bajo formas grupales o comunitarias, que defienden los «lugares» frente a los «espacios de flujos», la «memoria» y la historicidad frente al «tiempo intemporal», y los «valores trascendentes» frente a la pura «tecnología como valor». Comunidades religiosas, nacionalismo, etnicidad, identidad territorial, comunas feministas y de liberación sexual, ecologismo, etc. La resistencia a la lógica de la red y del capitalismo informacional procede de grupos y de comunidades. Sin embargo, debemos esperar, en opinión de Castells, que estas identidades de resistencia, que constituyen los verdaderos nuevos sujetos históricos del cambio, abandonen el cierre ensimismado que las caracteriza y se transformen en «identidades proyecto", es decir, identidades orientadas a la transformación de la sociedad en su conjunto (Castells, 1977b). El futuro, sin duda, resultará de la interacción entre el poder de las redes y el poder de la identidad.

\section{LA MUERTE DE LA RAZÓN CIENTÍFICA Y LA EMERGENCIA DEL SÍMBOLO}

A partir de la publicación de La condición postmoderna, Jean-François Lyotard se convirtió en una referencia obligada del pensamiento posmoderno, bien representado también por un conjunto de pensadores sociales franceses, en el que cabría incluir, entre otros, a Jacques Derrida, Jean Baudrillard, George Bataille, Michael Foucault y Gilles Deleuze. Lyotard distingue entre era posindustrial, que hace referencia a los cambios sociales, y era posmoderna, basada en unos determinados cambios culturales. De ahí que, para él, la posmodernidad sea ante todo «una disposición de ánimo o un estado de la mente», actitud o estado mental que identificó, en una famosa frase lapidaria, con «la incredulidad con respecto a los metarrelatos» (Lyotard, 1998: 10). Por metarrelatos entendía las «Grandes Narraciones» legitimadoras de la sociedad moderna. La fuerza legitimadora de la idea y creencia en Dios fue sustituida por grandes ideas y creencias como la de Progreso, Emancipación o llustración. El mismo marxismo no es para Lyotard sino una gran narración moderna que, invirtiendo el sentido idealista de la Historia, conduce a una tierra de Provisión. Lyotard también cuestiona la legitimidad de la Razón y de la Ciencia, así, con mayúsculas, poniendo de manifiesto que el saber científico se apoya en unos supuestos narrativos, o metarrelatos, que no son en sí mismos científicos. Tomando del filósofo Wittgenstein la idea de los «juegos de lenguaje», sostiene que incluso la misma ciencia, producto de la especialización de sus contenidos y de sus prácticas, se orienta a una fragmentación en segmentos inconmensurables dotados de una legitimidad exclusivamente particular y local. La ciencia, en el marco de una sociedad dominada por los ordenadores, pierde la legitimidad universal del gran relato y mercantiliza su conocimiento, que ya sólo puede justificarse por su rendimiento práctico y operativo. 
La pérdida de credibilidad universal propia de la modernidad da paso a la construcción de múltiples sentidos configurados localmente en el marco de juegos de lenguaje particulares, lo que posibilita la formación de puntos locales de resistencia frente a la hegemonía de la lógica del rendimiento y a la formación de consensos sociales absolutos y universales. Las visiones totalizantes de la modernidad quedan, por tanto, diluidas en la posmodernidad. Desde Comte a Luhmann, pasando por Marx, Durkheim o Parsons, la sociedad era vista bien como un todo orgánico y funcional, bien como un cuerpo dividido en dos mitades, pero de nuevo la pluralidad se impone, de nuevo las búsquedas de sentido recuperan su arraigo local y particular. Las aspiraciones a la universalidad se han terminado. El multiculturalismo se revela como lógica posmoderna de la construcción del sentido y la legitimidad.

La muerte de la Razón, quizá el rasgo más relevante asociado al fin de la sociedad moderna (Wellmer, 1998: 103), no se resuelve exclusivamente en el ámbito de la legitimidad otorgada al conocimiento científico. Pues este conocimiento, que pretende alcanzar la verdad objetiva del mundo exterior, se descubre a sí mismo en la voluntad de control y de dominio que lo anima. «La ciencia moderna nació de la irresistible ambición de conquistar la Naturaleza y subordinarla a las necesidades humanas» (Bauman, 1991: 39). Esta voluntad de dominio que anima a la ciencia moderna debemos entenderla como una triple dominación, que se despliega simultáneamente sobre el mundo natural, el mundo social y el mundo personal. Max Weber, en La ética protestante y el espíritu del capitalismo, muestra cómo la nueva cultura moderna trata de convertir toda la vida de un individuo, su biografía entera, en un constante, minucioso y metódico proyecto de control racional de la conducta orientado hacia el logro y el éxito intramundanos, logro que no podía llevarse a cabo, en último extremo, sin un férreo e inconsciente autocontrol emocional del sujeto (Elias, 1993) y sin un férreo control de las demás personas y de la naturaleza misma.

Zygmunt Bauman, en Modernity and ambivalence, desarrolla la tesis de que la modernidad puede ser considerada como una incesante lucha contra la ambivalencia, un esfuerzo continuo y denodado por construir "orden» social, estructuras definidas, clasificaciones claras, categorías exentas de ambigüedad, que alejaran el caos y la ambivalencia. Esta mentalidad intelectual geométrica, y esa vocación práctica orientada al diseño, la manipulación, la organización y la ingeniería, con el objeto de controlar el mundo y la vida misma, forman parte de la esencia de la modernidad. Horror al vacío, a la ambigüedad y a la ambivalencia, a la posibilidad de que algo sea nada, de no saber qué es algo, y de no poder asignar cada objeto, cada hecho o cada sujeto a una categoría determinada. El horror de todos los horrores, el genocidio nazi, no fue, en opinión de Bauman, el resultado de una descontrolada explosión de las pasiones ni un acto irracional carente de todo propósito. Muy al contrario, fue el resultado de una racionalizada ingeniería social orientada a producir el orden que por sí mismo la realidad social era incapaz de producir (Bauman, 1991: 38). En los albores 
de la sociedad posmoderna la ciencia pierde legitimidad, también y sobre todo, por los horrores de las guerras, por los horrores nucleares y por los potenciales horrores genéticos que puedan llegar. Se propone, entonces, una nueva cultura capaz de convivir con la indeterminación y la ambivalencia. Una nueva sociedad con una pluralidad de fuentes de poder y de autoridad tanto en la política como en el pensamiento. «Sólo el pluralismo devuelve la responsabilidad moral de las acciones a su portador natural: el actor individual» (Bauman, 1991: 51). Las autoridades absolutas producen una irresponsabilidad general. En la posmodernidad ninguna autoridad puede decirte qué es lo que debes hacer. Pero de esto se deriva, también, un riesgo de relativismo vacuo y de profundo nihilismo cultural.

Mientras que en Lyotard la incredulidad con respecto a los metarrelatos era sustituida por la formación de sentidos locales en el marco de específicos juegos de lenguaje, para Jean Baudrillard asistimos, en la era de los medios de comunicación electrónicos, a la pérdida total de sentido. Tres formas de comunicación se suceden: la que establecemos en las relaciones personales cara a cara; la que utiliza como medio la letra impresa, configurando la denominada por Marshall McLuhan Galaxia Guttenberg, y la que se produce por medio de la proliferación de imágenes electrónicas. También puede hablarse de tres formas de representación: desde el Renacimiento hasta la revolución industrial, las copias representaban o eran equivalentes al original; en la revolución industrial asistimos, merced a las posibilidades de reproducción mecánica, a una proliferación o masificación de las réplicas; tras la Segunda Guerra Mundial y la extensión de los medios de comunicación electrónica, especialmente la televisión, comienza una nueva fase en la que las copias y los modelos ya no tienen ningún referente real. Las imágenes ya no reflejan la realidad, sino que la conforman. Constituyen tanto el modelo desde el cual construimos nuestro mundo como el mundo en el que actualmente vivimos. La vida se convierte en televisión, se descompone en multitud de imágenes conformando un universo hiperreal de comunicación.

En esta fase, en contra de lo que pensaba Marx, la primacía de la producción y del intercambio de bienes es sustituida por la primacía del consumo y del intercambio de símbolos. Somos consumidores simbólicos porque en los signos se encuentra toda fuente de valor. Pero estos signos ya no refieren una realidad exterior, se configuran en una lógica de pura autorreferencia. Las imágenes no aluden a la realidad, sino a otras imágenes, y éstas a su vez a otras. La comunicación llega a ser un puro «simulacro» sin referente real. La simulación se impone, los significantes refieren otros significantes, y el significado por fin desaparece en esta marea de comunicaciones electrónicas masificadas. El sentido se disuelve. Queda el desierto y la nada. La Guerra del Golfo, según Jean Baudrillard, nunca existió. Baudrillard sostiene que en nuestra época se produce una simultánea «explosión de la información» y una «implosión del significado». En la medida que aumenta la cantidad de imágenes y de información, disminuye la producción de significado y de sentido. La cultura 
simbólica, constituida en realidad virtual y simulacro, domina nuestras existencias en un vacío de sentido. Desde este horizonte, los individuos de carne y hueso se convierten en pura «masa», y lo social se diluye en pura «audiencia».

\section{EL CAPITALISMO DE CONSUMOY EL PRINCIPIO DE PLACER}

La posmodernidad está íntimamente ligada a la emergencia del capitalismo de consumo. Bauman sostiene que, en la actualidad, el consumo constituye simultáneamente el «foco cognitivo y moral de la vida», el «vínculo integrador de la sociedad» y el «centro desde el que se gobierna el sistema». Es decir, ocupa la misma posición que en el pasado, esto es, en la fase «moderna» de la sociedad capitalista, ocupó el trabajo. Y esto significa que los individuos de nuestro tiempo están sobre todo implicados, moral y funcionalmente, en el sistema, antes como consumidores que como productores (Bauman, 1992: 49). El trabajo ha perdido centralidad para la vida individual y para el sistema social, y su ética, la moral del sacrificio y del esfuerzo, el «principio de realidad» que se impone para la consecución de logros materiales, ha sido sustituido por el «principio de placer». El capitalismo ha ubicado el placer en el ámbito del consumo y, con ello, en una sociedad de la abundancia, tiene asegurado más que nunca su porvenir como sistema. De hecho, «para el sistema de consumo, un consumidor felizmente dispendioso es una necesidad; para el consumidor individual, el dispendio es un deber» (Bauman, 1992: 50). De ahí que el sistema ejerza, mediante la publicidad y la comunicación, una presión hacia el gasto, presión que es vivida como alegría y goce tanto como opresión. En el orden del consumo, orientado por el principio del placer, la «seducción» constituye el instrumento básico de control social. En la sociedad de consumo, la libertad individual se transfigura en «libertad del consumidor», modelo al que se ajustan todos los esquema de libertad. Y esta libertad, más allá del consumo de masas, basado en la uniformidad, se transmuta en heterogeneidad que fragmenta las formas y estilos de vida de los individuos posmodernos (Bauman, 1992).

Daniel Bell, desde una posición neoconservadora, ha sostenido una tesis diferente a la de Bauman. Para Bell, la cultura moderna resulta ser autocorrosiva. Ella misma genera las bases que conducen a la desaparición de la ética del esfuerzo y de la renuncia, propia de la burguesía emprendedora que dio lugar al capitalismo, y ella misma crea la cultura hedonista del consumo de masas que subvierte los valores puritanos y pone en riesgo los logros alcanzados (Bell, 1976).

En cualquier caso, estamos pasando de un mundo de escasez, a uno de abundancia; de una moral de ahorro, a una de gasto y de consumo; de una ética de sacrificio, a una cultura hedonista; de un sujeto que renuncia al presente para ganar el futuro, a un sujeto del de- 
seo orientado por pautas de satisfacción inmediata; de un principio de realidad, a un principio de placer. Todos estos cambios tienen consecuencias tan radicales en la economía, en la sociedad, en la política, en la cultura y en la vida misma de los individuos que algunos pensadores sociales creen que las revoluciones del consumo y de las tecnologías de la información constituyen los dos pilares básicos de la posmodernidad.

Según afirma Marinas, siguiendo la hipótesis de Bataille, «la cultura de consumo instaura una racionalidad nueva que incluye el gasto y el despilfarro como funciones centrales» (Marinas, 2001: 22). Frente a la racionalidad económica moderna, basada en el cálculo y la utilidad, que demanda y exige como moral un uso productivo de las cosas, y por tanto una justificación exógena, Bataille revela la lógica del deseo gratuito que va más allá, y nunca se justifica, por el principio de utilidad. La moral moderna odia el dispendio, pero en el orden del consumo, y especialmente del consumo tradicional y posmoderno, la lógica del "gasto improductivo", de la pérdida injustificada, del despilfarro, del dispendio incondicional, se imponen. Bataille considera gastos improductivos el lujo, los lutos, las guerras, los cultos, los monumentos suntuarios, los juegos, los espectáculos, las artes, etc. Todos estos gastos presentan dos características: se justifican por sí mismos y tienen más valor cuanto mayor es la pérdida o gasto. El despilfarro en el consumo posmoderno es tan evidente que nadie se atreve ya a reflexionar sobre su justificación. La moda es en sí misma un despilfarro. El gasto en tallar las mil caras de un diamante es un despilfarro. Lo consumido en fiestas y alcohol es un despilfarro. El gasto estético, incorporado a todo consumo, es también un despilfarro. Producimos, podría decirse, con el único objeto de consumir, esto es, de dilapidar, despilfarrar y destruir. Somos y nos sentimos ricos cuando derrochamos alegremente, y sin justificación alguna, nuestros enormes recursos.

Podemos distinguir, atendiendo a sus motivaciones, tres tipos de consumo. Primero, el orientado según criterios de «necesidad», y cuyo modelo fisiológico sería el hambre y la correspondiente ingesta de pan. Segundo, el orientado por la «demanda», de naturaleza social, tal como pusieron de manifiesto Veblen al analizar el «consumo conspicuo», Simmel en su estudio de la moda, y Bourdieu con su investigación acerca de los criterios sociales del gusto y la lógica de la distinción. Y tercero, el orientado por el «deseo», de carácter individual, basado en la búsqueda de sensaciones y experiencias emocionales, basado en el sueño y en la fantasía, y basado en una ecuación personal de placer que se resiste a cumplir exclusivamente una función de marcaje o de distinción social. El consumo posmoderno, según Featherstone, se caracteriza por incorporar las motivaciones que corresponden al plano de la demanda y al plano del deseo, pero no en tanto opciones alternativas entre las que tenemos que elegir, sino como asunción simultánea de ambas (Featherstone, 1991: 27). La homogeneidad del consumo de masas se fractura en la posmodernidad con el objeto de servir a múltiples motivaciones híbridas que están a caballo entre los estándares 
sociales y los sueños individuales. Con este conjunto de necesidades, demandas y deseos, cada individuo teje y proclama a los otros su «identidad» personal y social en «estilos de vida" definidos mediante sus correspondientes estructuras de consumo. Featherstone cita la obra de Stuart y Elizabeth Ewen, Channels of Desire, para señalar que «hoy no hay moda, sino modas», que «no hay reglas, sino elecciones», y que «cada uno puede ser quien quiera». A lo que, para ser exactos, habría que añadir algo. El individuo posmoderno puede ser quien quiera a condición de que consuma, sea y viva, bien en «grupo» (lbáñez, 1979), bien en «tribu» (Maffessoli, 1990).

\section{LA HIPERMODERNIDAD DE LAS SOCIEDADES AVANZADAS}

Algunos pensadores sociales observan los cambios posmodernos como resultado de un proceso de hipermodernidad, de modernidad radicalizada o de modernidad reflexiva. Touraine, Habermas, Giddens o Beck no creen que los ideales y mecanismos de la modernidad estén trasnochados u obsoletos. Muy al contrario, están convencidos que más bien el problema radica en que el proceso de la modernidad ha sido truncado o desviado de sus objetivos y recursos originales, causando una evidente crisis y vacío de legitimidad. Para Touraine, «la crisis de la actual modernidad representa no el rechazo de la secularización y la confianza en la razón, sino una transición más completa, en la que la razón y el sujeto se afirmarán una vez más» (Lyon, 1999: 72-73). Habermas también cree que la modernidad es un proyecto inacabado, y confía en que la "acción comunicativa», basada en un diálogo libre y perfecto, reoriente la modernidad por el buen camino. La diferenciación de la cultura moderna es anunciada por Kant, en La crítica del juicio, con su doctrina de las tres esferas. La cultura queda segregada en tres ámbitos, el del «conocimiento», el de la «moralidad»y el de la «estética», operando cada uno en su interior con una lógica autónoma. En el sistema social, la diferenciación moderna establece los ámbitos de la política (poder), la economía (dinero), la comunidad social (influencia) y la vida privada (compromiso), cada uno de ellos operando también con su propia lógica (Crook, 1994: 27). Según Habermas, los ámbitos de la política y la economía constituyen los «sistemas directivos», que operan mediante la instrumentalización y la coerción del otro, y están motivados por el interés propio de cada individuo. Los ámbitos de la sociedad y la cultura constituyen el «mundo de la vida», y persiguen la formación de consensos mediante una acción comunicativa orientada al entendimiento con el otro. Para Habermas, el problema de la modernidad estriba en que la racionalidad instrumental de los sistemas directivos ha colonizado los ámbitos del mundo de la vida, y propone como solución de futuro que cada racionalidad vuelva a reinar en su propio ámbito. De este modo, y suponiendo que tal esperanza pueda llegar a realizarse (Picó, 1998: 41), el mundo de la vida quedaría liberado de la razón instrumental y técnica que lo domina. 
Según Anthony Giddens, estamos viviendo en un período de «alta» o «radicalizada» modernidad, cuyo proceso puede denominarse «modernización reflexiva». La aplicación de la racionalidad instrumental, en esferas hiperdiferenciadas del sistema social, resulta cada vez más compleja, por lo que la modernidad debe atender no sólo a los efectos deseados y primarios que resultan de sus acciones, sino también a las múltiples consecuencias indeseadas y latentes que siempre se producen por la complejidad de los actuales sistemas sociales. Estas consecuencias no deseadas son las que toma como referencia Ulrich Beck para formular su noción de «sociedad del riesgo», caracterizada funcionalmente por una producción sistemática de riesgos que escapan a las instituciones de control y de protección social. En la sociedad del riesgo, a diferencia de la sociedad moderna, el horizonte motivacional no es el de la consecución de bienes (renta, trabajo, seguridad social), sino el de la evitación de males, por lo que la distribución social de los riesgos se convierte en una clave de la política (Beck, 1997: 19). Los riesgos nucleares, ecológicos, genéticos o financieros constituyen en esta reflexión prototipos de riesgo, pues se caracterizan, primero, por ser riesgos creados por la propia sociedad y, segundo, por la general afectación social de sus efectos.

Cuanto más moderna es la sociedad, más consecuencias no deseadas produce (Beck, 2002: 189). Puede afirmarse, por tanto, que el conocimiento científico siempre avanzará por detrás de los hechos que la propia ciencia genera. El desconocimiento relativo, así como otros muchos factores propios de una segunda, reflexiva, tecnológicamente avanzada o radicalizada modernidad, generan profundas ansiedades, inseguridades e incertidumbres, al tiempo que desaparecen las ficciones de seguridad de la sociedad industrial. La «modernización reflexiva significa la posibilidad de una (auto)-destrucción creativa de toda una época: la de la sociedad industrial» (Beck, 1997: 14), «significa autoconfrontación con aquellos efectos de la sociedad del riesgo que no pueden ser tratados y asimilados dentro del sistema de la sociedad industrial» (Beck, 1997: 19). La nueva sociedad, dice Beck, no nace del dolor ni de la pobreza sino, paradójicamente, de la creciente riqueza material, del creciente desarrollo científico-tecnológico y de la elevada seguridad laboral lograda en la modernidad.

Los análisis de Scott Lash resultan de sumo interés porque representan un necesario intento de distinguir con precisión entre «hipermodernidad» o modernidad radicalizada y posmodernidad. Lash trata de defender el humanismo de la posmodernidad, señalando, por ejemplo, que el poder de los significantes sobre los significados, referido por Baudrillard o Lacan, no es un fenómeno posmoderno, sino hipermoderno, el resultado de una «hiperdiferenciación» entre significado y significante, ya presente en la obra de Saussure. Para Lash, sin embargo, la posmodernidad está marcada por una «de-diferenciación» en la cultura, así como por la relevancia de lo «figural» sobre lo «textual». A la «semiosis» 
(auto-referente) del texto le sigue la «mimesis» (hetero-referente) de las imágenes, el espectáculo, el cine o el vídeo. Lash, a diferencia de Giddens o Beck, resalta el hecho de que por las redes no sólo circula «conocimiento cognitivo», sino también «comunicación expresiva», lo que le permite conceptualizar la existencia de una «reflexividad estética» más allá de la «reflexividad cognitiva» que consideran exclusivamente estos autores. La tercera idea que distingue el concepto de reflexividad de Lash se basa en la consideración crítica de una reflexividad puramente individualista. Lash habla de «comunidades reflexivas» y de una «hermenéutica de la recuperación» que trata de «sacar a la luz los fundamentos ontológicos del ser-en-el-mundo-comunitarrio» (Lash, 1994: 181). El proyecto posmoderno, según Lash (Lash, 1991: 66), propone un regreso a valores históricos y un regreso al humanismo.

\section{LA GLOBALIZACIÓN DE LA ECONOMÍA Y DE LA CULTURA}

En el horizonte de la posmodernidad se destacan dos grandes transformaciones políticas: el declive del Estado-nación y la emergencia de nuevos movimientos sociales. La política de la modernidad estaba basada en la concentración del poder en un Estado que monopolizaba, en el interior del territorio nacional, el ejercicio legítimo de la violencia física. También se caracterizaba por el hecho de que la estructuración en clases del sistema capitalista determinaba los conflictos sociales, la distribución de recursos, las afiliaciones políticas y los votos electorales. Esta lógica del conflicto de clases dio paso a un contrato social, entre burguesía y trabajadores, del que emergió tras la Segunda Guerra Mundial el Estado de Bienestar, un Estado burocrático y corporativista, que regula las metas políticas y económicas de la modernidad mediante el acuerdo interclasista formalizado por sus organizaciones representantes, esto es, partidos políticos, sindicatos y organizaciones empresariales.

Los procesos de globalización de la economía y de la cultura, soportados sobre nuevas estructuras de movilidad material y comunicacional, están conformando un mundo que trasciende los límites de la moderna territorialidad estatal. El incremento de las interacciones e intercambios a escala global se corresponde con procesos paralelos tendentes a la constitución de nuevas instituciones y organizaciones supranacionales, interesadas bien en operar globalmente, bien en regular las operaciones y flujos de poder que circulan en este ámbito global. Empresas transnacionales, mafias internacionales, satélites de comunicaciones, movimientos migratorios, mercados económicos multinacionales, gendarmes globales, tribunales internacionales, organizaciones mundiales, etc., configuran un nuevo escenario en el que el Estado pierde el monopolio regulador que ejercía sobre la nación. El sistema político se fractura en múltiples centros de poder que compiten por la dirección del sistema global. Esto no significa que el Estado haya perdido todo su poder, 
pues sigue manteniendo cierto protagonismo. Pero cada vez más es una "cáscara vacía» que pretende más de lo que puede. En este nuevo contexto, como afirma Bell, el Estado es hoy «demasiado pequeño para los grandes problemas de la vida, y demasiado grande para los pequeños» (Smart, 1997: 136). Así que, junto a este proceso de hipercentralización y fracturación del sistema político en múltiples centros globalizados de poder, asistimos a un proceso simultáneo y complementario de descentralización y difusión del poder en instituciones infranacionales, en gobiernos regionales y locales. El Estado queda entonces como un mesogobierno que pierde funciones tanto en el ámbito supranacional como en el infranacional.

Alain Touraine, que ha otorgado en su obra especial importancia a este proceso, ya sostuvo en 1969 que debemos dejar de considerar a la «sociedad» como si fuera un personaje o unidad, y que debemos estudiar más atentamente las dinámicas del cambio social que se detectan desde una «sociología de la decisiones políticas», y desde una «sociología de la contestación» centrada en el análisis de los movimientos sociales (Touraine, 1969: 24). La política moderna, basada en el Estado-nación, en la viejas clases sociales, en un ethos burocrático-corporativista, en principios pragmáticos y tecnocráticos, en las distinciones de izquierda y derecha, en las organizaciones representativas formales, en la exclusiva participación electoral formalizada, en el conflicto de intereses económicos, en la diferenciación de la política como ámbito independiente del social o del cultural, esta política moderna, puede decirse, está siendo sustituida por otra que incorpora nuevos sujetos, formas, contenidos y lenguajes.

La expresión más evidente de esta reorientación en las estructuras y las sensibilidades del poder aparece con los nuevos movimientos sociales: ecologistas, pacifistas, defensores de los derechos humanos, feministas, antinucleares, antiglobalización, etc. En esta nueva forma de hacer política se detectan: una mayor interpenetración entre cultura y política, una pérdida de la relevancia de las fracciones de clase, menor interés por la economía, creciente interés por el activismo político no convencional, renovada importancia concedida a los valores, uso de símbolos con cargas afectivas y utilización estratégica de los medios de comunicación. Para Stephen Crook, los nuevos movimientos sociales se caracterizan por cinco rasgos. Primero, están animados por una moral universalista, una moral de la convicción ajena a motivos instrumentales o de interés. Segundo, están estructurados bajo criterios de autoorganización, alejados de la intermediación burocratizada y centralista. Tercero, dirigen sus acciones directamente a la gente o a la opinión pública, evitando cualquier acuerdo con las élites. Cuarto, operan en el ámbito sociocultural, otorgando a sus acciones un carácter lúdico y contracultural alejado del espíritu del político profesionalizado. Y quinto, dependen y basan su acciones en la notoriedad que logran, a través de los medios de comunicación, mediante dramatizaciones simbólicas e icónicas alejadas de las argumenta- 
ciones al uso en la política moderna. «Todos estos movimientos son policéfalos, polimorfos, inclusivos, ideológicamente plurales y programáticamente incoherentes. En esto reside tanto su fuerza como su debilidad» (Crook, 1994: 148-149). Por tanto, construiremos la sociedad posmoderna con una mezcla de la vieja y de la nueva política, con una mezcla de la hiperconcentración y la desconcentración típicas de las estructuras contemporáneas del poder.

\section{HACIA UNA CULTURA POSMATERIALISTA}

La importancia de la cultura, como rasgo determinante del cambio social posmoderno, ha sido resaltada por muy diversos autores. Sin embargo, ninguno de ellos ha llevado a cabo, durante varias décadas, un proyecto de investigación empírica internacional de envergadura similar al realizado por Ronald Inglehart. Utilizando un cuestionario común, se ha entrevistado a individuos de más de cuarenta nacionalidades, que representan más del setenta y cinco por ciento de la población mundial. Con esta investigación, dedicada al análisis del cambio de valores, se ha podido comprobar empíricamente que la cultura de la población mundial, y especialmente la de las sociedades tecnológicamente avanzadas, se está adaptando a los rasgos característicos de la cultura posmoderna. Ronald Inglehart inició su investigación para demostrar que, en las sociedades avanzadas, se estaba produciendo un profundo cambio cultural consistente en la progresiva sustitución de los valores «materialistas» por los valores «posmaterialistas».

Inspirado en la jerarquía de las necesidades humanas elaborada por A. H. Maslow, sostuvo la tesis de que las «necesidades materiales», básicamente el mantenimiento y la seguridad física, estaban perdiendo prioridad valorativa con respecto a las «necesidades no fisiológicas», como la estima, la pertenencia al grupo, la autoexpresión, la satisfacción intelectual o estética y la calidad de vida. Inglehart postula dos hipótesis para explicar este cambio. La primera, o «hipótesis de la escasez», señala que otorgamos mayor valor subjetivo a las cosas relativamente escasas, por lo que en una sociedad de la abundancia, en la que los milagros económicos de la modernización y el propio Estado de Bienestar han asegurado nuestra existencia material, tenderemos a valorar en mayor medida la satisfacción de las necesidades no fisiológicas. Es preciso hacer notar aquí que en este modelo la variable clave es el "grado subjetivo de seguridad", y no medidas objetivas de bienestar. La segunda, o «hipótesis de la socialización», señala que los valores no se ajustan de modo inmediato a las nuevas situaciones, sino que requieren un tiempo para afectar, por medio de la socialización, a las nuevas generaciones (Inglehart, 1991: 61). Inglehart nos dice que este cambio podría explicarse por el «principio de utilidad marginal decreciente del determinismo económico», que llevaría a una valoración marginal decreciente de las necesida- 
des materiales. Esto no significa que los posmaterialistas sean no-materialistas, y menos aún anti-materialistas. «El término "posmaterialista" denota un conjunto de metas a las que la gente da importancia después de haber alcanzado esa seguridad material» (Inglehart, 1998: 45). Norbert Elias expresaba una idea similar al afirmar que en el siglo xx el «progreso es sin duda un hecho, pero para muchas personas ha dejado de ser un ideal»" (Elias, 1993: 22-30), esto es, un valor, una esperanza o una ilusión.

El resultado más importante que emerge del análisis de la Encuesta Mundial de Valores es la existencia de dos ejes o «factores morales» que explican una gran parte de la varianza existente en las «opiniones valorativas» registradas por la encuesta. El primero recoge el contraste entre los valores «tradicionales» y los «secular-racionales», mientras que el segundo discrimina entre los valores de «supervivencia» y los de «auto-expresión» (Inglehart, 1998: 109). Dicho de otra forma, el primero expresa el contraste entre la cultura de la sociedad tradicional y la de la sociedad moderna, y el segundo expresa el contraste entre los valores de la sociedad moderna y los de la sociedad posmoderna (Pino y Bericat, 1998: 15). Según Inglehart, la sociedad tradicional, orientada hacia la supervivencia material, en el marco de una economía pobre y estacionaria, tiene que limitar las aspiraciones de logro para evitar la frustración. También tiene que controlar la utilización de la violencia física, única vía de un posible enriquecimiento en este contexto, mediante rígidas normas religiosas y comunitarias y una fuerte autoridad de tipo tradicional. La sociedad moderna estimula las motivaciones de logro y se propone como meta la maximización del crecimiento económico, en un contexto de rápida acumulación de capital regido por una racionalización que modifica el tipo de autoridad vigente, pasando a ser racional-legal. La sociedad posmoderna, por último, se orienta hacia metas de maximización del bienestar subjetivo y de la calidad de vida, deslegitima tanto la autoridad tradicional como la legal-racional, e incrementa el valor de la autoexpresión y de la autorrealización individual (Inglehart, 1998: 101).

El posmaterialismo «parece ser sólo un aspecto de un proceso de cambio cultural aún más amplio que está recreando y transformando las orientaciones religiosas, los papeles y costumbres sexuales y las normas culturales de la sociedad industrial» (Inglehart, 1991: 59). De ahí que se observen correlaciones empíricas con la legitimidad otorgada a los nuevos movimientos sociales, la participación e implicación políticas, las necesidades de autoexpresión, el grado de espiritualidad, las motivaciones de prestigio, la solidaridad social, los valores laborales de creatividad e innovación, la tolerancia moral, política y social, y otros tantos valores posmodernos. Especial comentario requieren los valores religiosos, pues los análisis ofrecen resultados aparentemente paradójicos. En las sociedades avanzadas, las instituciones religiosas establecidas están perdiendo la lealtad de los fieles, pero existe un creciente interés por las preocupaciones espirituales en el plano individual; la 
asistencia a los oficios religiosos no ha dejado de disminuir y, sin embargo, persisten las creencias religiosas y aumenta la espiritualidad. «Un declive en la prevalencia de valores religiosos tradicionales caracteriza a la industrialización, pero no necesariamente a la fase postindustrial» (Inglehart, 2000). La desafección institucional religiosa convive, sobre todo en las sociedades posmodernas y en los individuos posmodernos, con un incremento de las demandas espirituales. Simmel, como vimos en otro fragmento, lo había intuido ya.

\section{LA HIPÓTESIS DE LA BIFURCACIÓN POSMODERNA}

De entre todas las maravillosas ficciones que Jorge Luis Borges creó, existe una en particular que siempre ha ejercido sobre mí una especial fascinación. Se titula El jardín de senderos que se bifurcan. El cuento narra la historia de un espía, bisnieto de Ts'ui Pên, que llega a la casa de un hombre, llamado Stephen Albert, con la pretensión de matarlo. En esa casa, antes de cometer el asesinato, descubre la clave del misterioso legado de su bisabuelo. «Ts'ui Pên, que fue Gobernador de Yunnan, su provincia natal, docto en astronomía, en astrología y en la interpretación infatigable de los libros canónicos, ajedrecista, famoso poeta y calígrafo, lo abandonó todo para componer un libro y un laberinto. A este empeño dedicó los quince últimos años de su vida, muriendo en el Pabellón de la Límpida Soledad. Nadie hasta ahora había encontrado el laberinto, y la novela, publicada por un monje en contra de la opinión de su familia, que deseaba quemarla, era un borrador compuesto de manuscritos incoherentes. En el tercer capítulo el héroe muere, pero en el cuarto está vivo. Ts'ui Pên había dejado escrito: Dejo a los varios porvenires (no a todos) mi jardín de senderos que se bifurcan. La frase "varios porvenires", sugirió la imagen de la bifurcación en el tiempo, no en el espacio. El laberinto que habían estado buscando era la propia novela. En todas las ficciones, cada vez que un hombre se enfrenta con diversas alternativas, opta por una y elimina las otras; en la del casi inextricable Ts'ui Pên, opta — simultáneamente- por todas. Crea, así, diversos porvenires, diversos tiempos, que también proliferan y se bifurcan. En la obra de Ts'ui Pên, todos los desenlaces ocurren; cada uno es el punto de partida de otras bifurcaciones. El jardín de senderos que se bifurcan es una enorme adivinanza, o parábola, cuyo tema es el tiempo» (Borges, 2001).

El proceso de modernización siempre se ha entendido desde una lógica disyuntiva y antitética. Todos los sociólogos clásicos que analizaron el gran cambio acontecido desde la sociedad tradicional a la sociedad moderna, Marx, Comte, Tönnies, Durkheim o Weber, pusieron de manifiesto la oposición existente entre los rasgos que caracterizaban a ambos tipos de sociedad. Modo de producción precapitalista versus capitalista, sociedad agraria versus sociedad industrial, comunidad versus sociedad, solidaridad mecánica versus solidaridad orgánica, racionalidad sustancial versus racionalidad instrumental. Esta lógica 
disyuntiva y antitética implicaba, en el orden pragmático, que cualquier avance de la modernización sólo podría realizarse con retrocesos paralelos de la tradición. La ciencia avanzaba destruyendo el mito; el capitalismo desvinculando a los siervos de la gleba; la secularización eliminando el poder y la legitimidad religiosa, o el individualismo debilitando los lazos familiares. Hacia la mitad del siglo xx, Talcott Parsons sintetizó con precisión este enorme cambio cultural recurriendo a cinco variables-pauta, cinco opciones valorativas antitéticas, que orientaban a cada tipo de sistema social. Estas pautas son: difusividad versus especificidad; particularismo versus universalismo; adscripción versus adquisición; emotividad versus neutralidad afectiva, y orientación colectiva versus orientación individual.

Muchos de los pensadores y científicos sociales que presencian en la actualidad el nuevo gran cambio, desde la sociedad moderna a la sociedad posmoderna, no pueden evitar caer en la tentación de seguir aplicando la lógica disyuntiva y antitética con la que se comprendieron las transformaciones desde la sociedad tradicional a la moderna. Creo, sin embargo, que quienes así proceden incurren en un craso error, pues tanto el advenimiento como la naturaleza de la posmodernidad están animados por una lógica radicalmente diferente, no por una lógica disyuntiva y antitética, sino por una lógica conjuntiva y sintética. La aplicación de una lógica disyuntiva al entendimiento de los cambios que están sufriendo las sociedades avanzadas vela de raíz y radicalmente nuestra mirada. Sólo seremos capaces de captar cognitiva, valorativa y emotivamente la posmodernidad, y sus procesos, desde una radicalmente nueva epistemología vital de la bifurcación. El proceso de la posmodernidad aparece ante nuestros ojos como un desarrollo bifronte y bifurcado. La verdadera naturaleza de la posmodernidad, como la de Jano, a quien Saturno premió con la facultad de conocer el pasado y el porvenir, sólo se revela al observar simultáneamente sus dos caras.

A mi entender, el proceso de posmodernización constituye el despliegue bifurcado y simultáneo de la modernidad por dos senderos, uno por el que caminamos hacia la hipermodernización y otro por el que avanzamos re-actualizando la tradición. Todos los fenómenos radicalmente nuevos a los que hemos denominado posmodernidad surgen desde la confluencia de ambas tensiones, emergen de la fusión fragmentada de los caudales que llevan esos dos grandes cauces de la naturaleza humana. El gran número de nuevos fenómenos sociales, políticos, culturales y personales que se han expuesto en los fragmentos precedentes ya no pueden calificarse ni de modernos ni de tradicionales. Si bien configuran su realidad desde los rasgos correspondientes a los dos polos de la antinomia, el resultado obtenido por la fusión y la síntesis constituye una realidad completamente nueva. De ahí que podamos hablar de una nueva sociedad, la sociedad posmoderna, en la que aparecen pautas y estructuras sociales de actividad simbióticas diferentes a las de las sociedades anteriores. En el ámbito cultural, la posmodernidad también se expresa en la sín- 
tesis de nuevos valores, producto de la formación de un consenso bifurcado en la confluencia y en el contraste de valores hipermodernos $y$ tradicionales. Los seres humanos posmodernos existirán en nuevos contextos vitales producto de la fusión de hipermodernidad $y$ tradición, y sentirán cada vez más intensa y simultáneamente estas nuevas demandas en las que se puede escuchar al unísono el eco de la hipermodernidad y el de la tradición. Esta lógica sintética y conjuntiva desde la que emerge una realidad radicalmente nueva es la clave del cambio social posmoderno.

Las causas que animan el cambio social posmoderno operan con la doble dialéctica que se establece entre las virtudes y defectos, y entre las consecuencias positivas y negativas, inherentes tanto a la modernidad como a la tradición. Constituye un claro error creer que la posmodernidad surge exclusivamente de las consecuencias de la modernidad. Es cierto que la modernidad se transmuta en hipermodernidad merced a la gran atracción que ejercen sus virtudes, así como a las consecuencias deseadas e indeseadas que se derivan de la aplicación de sus principios. Pero también es cierto que el cambio posmoderno sólo puede entenderse reconociendo la atracción que, en un contexto de hipermodernidad, ejercen las virtudes y funcionalidades asociadas al modo de vida tradicional. Sin este doble contraste de consecuencias y de atracciones no puede entenderse el giro posmoderno. En suma, virtudes de la modernización que se proyectan al futuro en consecuencias deseables e indeseables como hipermodernización, y virtudes de la tradición que se renuevan en este contexto de hipermodernización. Ambos polos, modernidad y tradición, contienen atractores y repulsores, consecuencias deseadas e indeseadas, que establecen una compleja dialéctica de cambio social desde la que está emergiendo una posmodernización que no muestra, al menos por ahora, cuál será su destino definitivo, su límite o su punto final.

La dialéctica de defectos y de consecuencias indeseadas puede entenderse en parte con la metáfora del péndulo. Cuanto más se eleva el contrapeso hacia un lado, mayor es la fuerza que empuja en el sentido contrario. Si nos desviamos excesivamente por la senda del individualismo, acabaremos estando y sintiéndonos solos, y el anhelo de establecer vínculos sociales crecerá en intensidad. $\mathrm{Si}$, convencidos de las virtudes de la planificación racional, pretendemos llevar el principio hasta el extremo, y planificamos completamente la vida o la economía de un país, empezaremos a ver cómo aparecen las consecuencias perversas de la ineficiencia, en el plano organizativo, y de la falta de libertad, en el plano personal. En esta dialéctica de la bifurcación, las virtudes contenidas en cualquier principio se transmutarán, a partir de cierto límite, en consecuencias indeseadas, y los defectos del principio opuesto comenzarán a aparecer como virtudes con consecuencias deseables. Y también a la inversa. Como sostiene acertadamente Stephen Crook, un mismo principio dinámico simple puede producir muy diferentes efectos de acuerdo con la fase, el ritmo o la amplitud de su aplicación. 
Adorno y Horkheimer, en su Dialéctica de la ilustración, aluden a este proceso cuando sostienen que el destino de la racionalidad instrumental es negarse a sí misma. Sus razones pueden engendrar monstruos, como la bomba nuclear, que claman por un retorno de la racionalidad sustancial, la que piensa también los fines, y no sólo los medios. Weber nos alertó de la jaula de hierro y del desencantamiento del mundo que llegaría con la racionalización. Baudrillard nos muestra cómo la explosión de información provoca una implosión del significado y del sentido. Beck afirma que la autoconfrontación de la modernidad con sus propios límites, con aquellos problemas que ella ha creado y es incapaz de resolver, forma la base de la segunda modernidad. Inglehart habla del principio de utilidad decreciente del principal logro de la modernidad, esto es, del bienestar material, y de cómo la seguridad que produce sienta las bases de una reorientación cultural. Elias nos muestra que una meta alcanzada, convertida en hecho, deja de ser una ilusión. Como observa Bataille, los principios de utilidad y cálculo se transmutan con la abundancia en despilfarro y gasto improductivo. La sociedad del riesgo surge de una sociedad que ha alcanzado altos grados de control pero que siente, paradójicamente, una ansiedad y miedo profundos ante el mínimo descontrol. Cuando el mundo se hace demasiado grande, observa Castells, los actores sociales pretenden reducirlo de nuevo a su tamaño y alcance.

Antes de exponer unos argumentos de autoridad y unos ejemplos en defensa de la hipótesis de la bifurcación posmoderna, quisiera hacer tres comentarios. El primero, de gran importancia para evitar confusiones conceptuales indeseables, tiene por objeto distinguir claramente entre tradición, que es el concepto usado en nuestra hipótesis, y tradicionalismo. Entiendo por tradicionalismo el retorno a los patrones adaptativos que adoptó, en su específico contexto de existencia, la sociedad tradicional. Por tradición, sin embargo, ha de entenderse el conjunto de recursos y virtudes que utilizaron los seres humanos para adaptarse en ese específico contexto vital. Inglehart habla de un retorno selectivo a la tradición, pero eso no es todo. La hipótesis de la bifurcación no sostiene que la posmodernidad vaya a recuperar el sistema patriarcal, la pena de muerte, la penalización de la homosexualidad y del divorcio, o una institución central de la moralidad. Éstas fueron pautas o formas adaptativas concretas, que no volverán. Lo que pretende poner de manifesto es que el modo de vida tradicional surgió de la aplicación de unos recursos, potencialidades o virtualidades humanos, de carácter universal e intemporal, a un contexto específico, y que estos recursos, potencialidades y virtualidades, que fueron en gran parte reprimidos por la sociedad moderna, serán re-activados, re-adaptados y re-actualizados en un nuevo contexto de hipermodernización. Por ejemplo, la posmodernidad busca un retorno a la moralidad, pero, como sostiene Luckmann, no a través de una institución moral central, sino mediante la implantación de una «moralidad-en-uso» descentrada e indirecta que circula en las comunicaciones de los sujetos posmodernos. El retorno a la espiritualidad y a la seguridad ontológica no será un retorno a formas religiosas dogmáticas, sino a una espiritualidad subjetiva, 
anclada en polifacéticas comunidades espirituales, en el marco de un mercado religioso plural. El honor y la vergüenza como modo de control social (Scheff, 1990), más allá del modelo de control moderno basado en la culpa, retornará ahora en la estructura relacional de la red. La aplicación estricta o el retorno formal a pautas tradicionales da lugar a lo que denomino patologías tradicionalistas, que son respuestas ciegas y desesperadas a la hipermodernización. Estas patologías, como el fundamentalismo religioso, las sectas llamadas peligrosas, el nacionalismo excluyente, etc., hacen que sigamos pensando que todo retorno tradicional es tradicionalista, lo que impide que comprendamos, aceptemos y creemos cauces no patológicos por los que puedan expresarse las demandas inspiradas en una voluntad y necesidad de recuperar la tradición.

El segundo comentario está dirigido, también, a evitar una confusión terminológica, bastante común, entre «posmodernismo cultural» y «cultura posmoderna». La cultura posmoderna es, en el sentido antropológico del término, la cultura que la población en general va adquiriendo en este nuevo contexto social, mientras que el posmodernismo es un movimiento cultural formado por intelectuales y artistas. En su papel de partera de la historia, este movimiento ha enfatizado en exceso algunos rasgos de la cultura posmoderna, ofreciendo de este modo una idea un tanto sesgada de esta cultura posmoderna, es decir, de las ideas, creencias, normas y valores, etc., que está adquiriendo la población general. Pese a que los modernos han acusado a los «posmodernistas» de irracionales, antimodernos o tradicionalistas, como en su día lo hiciera Habermas, lo cierto es que los «posmodernos» no son ni antimodernos ni tradicionalistas. He demostrado empíricamente, mediante análisis de encuesta, que los individuos posmodernos, siguiendo la hipótesis de la bifurcación, se adhieren a unos nuevos valores en cuya síntesis combinan la valoración dialéctica de recursos asociados a la modernidad y de recursos asociados a la tradición (Bericat, 1999). Por ejemplo, son más ecologistas, pero lo son en la medida que quieren encontrar un nuevo balance entre el desarrollo económico y la defensa del medio ambiente. También conceden una mayor importancia al ocio, pero esto no significa que dejen de valorar en alto grado el trabajo.

El tercer comentario tiene por objeto clarificar la hipótesis de la bifurcación posmoderna mediante el contraste con el modelo de posmodernidad expuesto por Crook, Pakulski y Waters (Crook, 1994). Estos autores parten de una primera tesis en la que sostienen que la posmodernización significa llevar a niveles extremos los elementos básicos de la modernización. Según esto, la posmodernidad implica una hiperindustrialización, una hiperdiferenciación tanto cultural como social, una hipercentralización política, etc. En suma, una hipermodernización. En segundo lugar, establecen interesantes argumentos, conectados a la visión de la posmodernidad de Lash, y que en gran medida comparto, sobre el hecho de que una hiperdiferenciación puede entenderse como una de-diferenciación. Sostienen que 
conforme avanza la diferenciación y aparece la hiperdiferenciación, las esferas se disuelven en fragmentos que sólo adquieren una caleidoscópica unidad en una poscultura de-diferenciada. En tercer lugar, los autores proponen dos sucesiones paralelas del cambio histórico. Una a la que denominan «dialéctica de la diferenciación», y otra a la que denominan «dialéctica de la desorganización», es decir, una cultural y otra social. En ambas versiones se destacan tres fases del proceso: a) diferenciación, b) hiperdiferenciación y c) de-diferenciación; a') organización, b') hiperorganización y c') desorganización. Pues bien, estas versiones no se corresponden con la hipótesis de la bifurcación, que, en sus mismos términos, expresaría la fases del siguiente modo: a) indiferenciación, b) diferenciación y c) hiperdiferenciación y de-diferenciación. La fase a) corresponde a la sociedad tradicional, antes de que la diferenciación cultural se produjese (Kant) y antes de que la diferenciación social tuviese lugar (Durkheim). La fase b) corresponde a la sociedad moderna. $Y$ en la fase c), posmoderna, observamos simultáneamente hiperdiferenciación y de-diferenciación. La unidad no es una unidad indiferenciada, como lo fue en la sociedad tradicional, sino una unidad caleidoscópica compuesta de retazos hiperdiferenciados, esto es, una unidad fractal. Vemos, pues, que la lógica conjuntiva y sintética no es una lógica de unidad magmática o tradicional, sino una lógica de unidad o síntesis fractal que opera con los fragmentos diferenciados previamente por la hipermodernización. La posmodernidad, aunque hunde sus raíces en la dialéctica bifurcada de la modernidad y de la tradición, crea hechos radicalmente nuevos que en ningún caso son ni modernos ni tradicionales.

De justicia es reconocer que estos mismos autores, Crook, Pakulski y Waters, pese a la sucesión de etapas expuesta, afirman en otro lugar que el desconcertante espectáculo ofrecido por los procesos contemporáneos de cambio es uno en el que la hiperconcentración y la desconcentración parecen ir cogidas del brazo. Touraine también afirma que la nueva cultura posindustrial, al mismo tiempo que es hipermoderna, rompe con la teoría de la modernidad; que la modernidad no destruye la tradición, sino que ésta es una fuente de su propia transformación. Smart se pregunta si la posmodernidad es una consecuencia exclusiva de la modernidad, y representa un efecto de la resistencia, regeneración o reconstitución de las formas de vida tradicionales, y/o significa una articulación de formas tradicionales $y$ modernas en diversas formas complejas y no anticipadas. Es evidente que la bifurcación posmoderna se corresponde con la segunda alternativa expuesta. Para Bauman, la posmodernidad es la modernidad arreglándoselas con su propia imposibilidad y, por tanto, implica una pérdida de confianza en el proyecto de la modernidad. Más conocimiento no significa menos ignorancia, nos dice, porque el crecimiento del conocimiento expande el campo de la ignorancia. El re-encantamiento posmoderno trata de recomponer el desencantado mundo de la modernidad. Heller y Feher sostienen que no hay una única, predestinada o necesaria agenda de la posmodernidad, que es intrínsecamente evidente que la posmodernidad presenta una doble cara. Said destaca que nuestro destino hoy es 
experimentar complicadas mezclas y combinaciones, y Arnason pone de manifiesto la reactivación de la tradición en el seno de la modernidad, así como el hecho de que la síntesis de tradición y modernidad debe ser vista como una matriz de futuros cambios. Para Berger, la modernidad se funde con una afirmación y reconstitución de la tradición. Castells nos muestra en su obra las mil dualidades y paradojas de la bifurcación del nuevo mundo: espacio de flujos $y$ espacio de lugares; memoria $y$ tiempo inmemorial; valores trascendentes y tecnología como valor; élites globales $y$ gente atraída por la identidad local; globalización del capital $y$ poder descentralizador de las redes, la «red» $y$ el «yo», la «sociedad red» $y$ el «poder de la identidad». Jameson opina que toda teoría correcta de lo posmoderno debería registrar este proceso de una conciencia histórica esquizofrénica. Lyon es partidario de considerar nuestra situación actual producto de la compleja interacción de lo premoderno, lo moderno y lo posmoderno. Para Featherstone, dentro de la cultura contemporánea del consumo, a los hombres y a las mujeres no se les pide que elijan, sino que incorporen las dos opciones. Giner señala que hay una bifurcación grave entre la filosofía analítica y el pensamiento social y económico racionalista, por un lado, y el modo de pensar irracionalista, llamado posmoderno, por el otro. Berlin expone con su peculiar maestría, en Las raíces del romanticismo, la dialéctica entre el clasicismo y el romanticismo moderno, dialéctica que alimenta, a nuestro entender, la posmodernidad. Juan Gris, un gran artista español, obcecado y olvidado, no tuvo otro empeño en su vida que recomponer una unidad trascendente con los fragmentos o retazos de lienzo con los que había de enfrentarse, en el proceso de creación, un pintor cubista.

La nueva síntesis posmoderna, que, como hemos visto, afecta a tantos ámbitos de la sociedad, de la política, de la cultura y de la vida individual, inaugura también, y por último, una nueva estructura socioemocional. Las tres emociones estructurales de la posmodernidad son la alegría, la ansiedad y la nostalgia. La posmodernidad es una sociedad de la abundancia, del consumo, del ocio, de la seguridad laboral, del espectáculo y del entretenimiento, de la democracia y de la libertad, de la reducción del esfuerzo merced a la tecnología, de la tolerancia, de la libertad sexual y del turismo. Una hipermodernidad que disfruta con alegría de los logros alcanzados por la modernización, una sociedad satisfecha, hedónica y derrochadora. Ahora bien, esta alegría posmoderna nunca alcanza a ser goce profundo porque el sujeto posmoderno con frecuencia olvida el valor y el esfuerzo de lograr los bienes de los que disfruta. Jameson, entre otros, pone de manifiesto la falta de profundidad vital de esta alegría, el hecho de que rezume superficialidad por los cuatro costados. De ahí que el sujeto posmoderno tenga que recurrir a las drogas, como el éxtasis, o a sistemas productores de intensas sensaciones y excitaciones emocionales, para obtener un goce intenso y sentir la emoción súbita e instantánea de la euforia. Los parques temáticos divierten, pero nunca producen auténtico placer. De esta alegría superficial nace la carencia y el deseo posmodernos de un auténtico goce. 
La segunda emoción estructural es la ansiedad. Bauman y Giddens nos alertan de la necesidad que tenemos de aprender a vivir en un estado crónico de ambivalencia y de contingencia, más allá de una imposible seguridad ontológica tradicional y más allá del control absoluto proyectado por la propia modernidad. Ambivalencia radical porque en la bifurcación el bien y el mal habitan muchas veces la misma morada, porque estamos obligados a convivir con opciones contrapuestas. La energía nuclear es la más barata y limpia, salvo que estalle el reactor. En este caso se convierte, sin duda, en la más cara, desoladora y contaminante. La ciencia procura buena cantidad de bienes, pero tememos profundamente sus consecuencias indeseables. Sennet muestra la contingencia y la corrosión del carácter en estos tiempos posmodernos, y Gil Calvo sostiene que hemos nacido para cambiar, cambiar de cónyuge, de trabajo, de vida y de identidad. La ansiedad posmoderna es radicalmente diferente a la angustia moderna, expresada en el cuadro El grito, de Edward Munch, así como al temor reverencial que inspiraban la Naturaleza y los Dioses premodernos. La ansiedad, producto de la ambivalencia y de la contingencia, se nutre de la incertidumbre. Es una nueva síntesis de miedo y esperanza, las dos emociones que, según Hume, se basan en la «probabilidad» de que algo bueno o algo malo pueda sucedernos.

En último lugar, pero no por ello menos importante, encontramos la emoción estructural de la nostalgia, un término y un sentimiento reciente en la historia de la humanidad. No podía existir en la sociedad tradicional porque sus ciclos siempre actualizan el pasado en un eterno retorno que fundaba cada presente. Por tanto, no cabe el dolor ni la tristeza del recuerdo excitado por la carencia de algún bien perdido. En la sociedad moderna, empeñada en destruir el pasado y olvidar el presente convirtiéndolo en ilusión de futuro, la añoranza y la nostalgia, aunque existentes, eran reprimidas u omitidas en la medida que la ilusión de modernidad dominaba la cultura. Conforme avanza la hipermodernidad, conforme el futuro deja de ser una ilusión, el sujeto posmoderno comienza a sentir y ser consciente de una pérdida absoluta e irreparable, una pérdida de gran valor. Entonces aparece la nostalgia, evidente en muchos autores, como Baudrillard, Bell o Jameson, y en las demandas de muchos individuos posmodernos. Nostalgia, muy evidente en los viajeros románticos, por la pérdida de los recursos y virtudes del mundo tradicional, por la pérdida de la autenticidad, de la comunidad, de la emoción, del mito y del encanto. Nostalgia, incluso, del sufrimiento y del dolor, del esfuerzo, de la responsabilidad, del honor y del verdadero amor. Nostalgia unamuniana de personas de carne y hueso, o, como señala Turner, de tiempo, de espacio y de sexo real ajenos al canto de sirena y a las promesas de la virtualidad.

El título del cuento de Jorge Luis Borges contiene las claves de la nueva experiencia vital posmoderna, de la experiencia en una nueva sociedad posmoderna. Sentimos la alegría de vivir en el jardín de la hipermodernidad; sentimos la ansiedad de encontrarnos en la en- 
crucijada de dos senderos que se bifurcan; sentimos nostalgia, por último, para construir un futuro jardín en el que no tengamos que lamentar ninguna pérdida.

Vivimos en el jardín de senderos que se bifurcan.

\section{BIBLIOGRAFÍA}

ANDERSON, P. (2000): Los orígenes de la posmodernidad, Barcelona, Anagrama.

BAUMAN, Z. (1991): Modernity and ambivalence, Cambridge, Polity Press.

- (1992): Intimations of Postmodernity, Nueva York, Routledge.

BECK, U. (1997): «La reinvención de la política: hacia una teoría de la modernización reflexiva», en U. Beck, A. Giddens y S. Lash, Modernización reflexiva. Política, tradición y estética en el orden social moderno, Madrid, Alianza.

- (1998): La sociedad del riesgo. Hacia una nueva modernidad, Barcelona, Paidós.

- (2002): La sociedad del riesgo global, Madrid, Siglo XXI.

BECK, U.; GIDDENS A., y LASH, S. (1997): Modernización reflexiva. Política, tradición y estética en el orden social moderno, Madrid, Alianza.

BELL, D. (1976): El advenimiento de la sociedad postindustrial, Madrid, Alianza.

— (1996): Las contradicciones culturales del capitalismo, Madrid, Alianza.

BERICAT ALASTUEY, E. (1994): Sociología de la movilidad espacial, Madrid, Centro de Investigaciones Sociológicas (CIS).

- (1996): «La sociedad de la información. Tecnología, cultura y sociedad», en Revista Española de Investigaciones Sociológicas (REIS), n. ${ }^{\circ}$ 76, pp. 141-170.

— (1999): «Individualismo y valores socioeconómicos», en F. Requena (coord.), Sociedad, cultura y desarrollo, Málaga, UMA.

- (2000): «La sociología de la emoción y la emoción de la sociología», en Papers, n. 62, pp. 145-176.

- (2001): «El suicidio en Durkheim o la modernidad de la triste figura», en Revista Internacional de Sociología (RIS), n. ${ }^{\circ} 28$, pp. 69-104.

- (2001): «Max Weber o el enigma emocional del origen del capitalismo», en Revista Española de Investigaciones Sociológicas (REIS), n. ${ }^{\circ}$ 95, pp. 9-36.

- (dir.) (2003): El conflicto cultural en España: Acuerdos y desacuerdos entre los españoles, Madrid, Centro de Investigaciones Sociológicas.

BERLIN, I. (2000): Las raíces del romanticismo, Madrid, Taurus.

CASTELLS, M. (1996): La era de la información. Economía, Sociedad y Cultura. Vol. 1. La sociedad Red, Madrid, Alianza.

- (1997a): La era de la información. Economía, Sociedad y Cultura. Vol. 2. El poder de la identidad, Madrid, Alianza. 
CASTELLS, M. (1997b): La era de la información. Economía, Sociedad y Cultura. Vol. 3. Fin de milenio, Madrid, Alianza.

CROOK, S.; PAKULSKI, J., y WATERS, M. (1994): Postmodernization. Change in advance society, Londres, Sage.

DíEZ NICOLÁS, J. (2000): «La escala de postmaterialismo como medida del cambio de valores en la sociedades contemporáneas», en F. Andrés y J. Elzo (dirs.), España 2000, entre el localismo y la globalidad, Madrid, SM.

ELIAS, N. (1993): El proceso de la civilización, Madrid, FCE.

FEATHERSTONE, M. (1988): «In Pursuit of the Postmodern: An Introduction», en Theory, Culture and Society, vol. 5, pp. 195-215.

- (1991): Consumer Culture \& Posmodernism, Londres, Sage.

FRISBY, D. (1998): «George Simmel: Primer sociólogo de la modernidad», en J. Picó, Modernidad y Postmodernidad, Madrid, Alianza.

GIL CALVO, E. (2001): Nacidos para cambiar. Cómo construimos nuestras biografías, Madrid, Taurus.

GINER, S. (1997): «Tiempos paralelos: el clima moral finisecular», en Boletín Institución Libre de Enseñanza, n. ${ }^{\circ}$ 2829, pp. 63-83.

- (2001): Teoría sociológica clásica, Barcelona, Ariel.

HABERMAS, J. (1998): «Modernidad versus postmodernidad», en J. Picó, Modernidad y Postmodernidad, Madrid, Alianza.

IBÁÑEZ, J. (1979): Más allá de la sociología: el grupo de discusión, teoría y crítica, Madrid, Siglo Veintiuno.

INGLEHART, R. (1991): El cambio cultural en las sociedades industriales avanzadas, Madrid, CIS.

- (1998): Modernización y posmodernización. El cambio cultural, económico y político en 43 sociedades, Madrid, CIS.

INGLEHART, R., y BAKER, W. E. (2000): «Modernization, cultural change and the persistence of traditional values», en American Sociological Rewiew, vol. 65, pp. 19-51.

JAMESON, F. (1998): Teoría de la posmodernidad, Valladolid, Trotta.

KELLNER, D. (1999): «Theorizing the present moment: Debates between modern and postmodern theory», en Theory and Society, n. ${ }^{\circ} 28$, pp. 639-656.

LAMO DE ESPINOSA, E. (1996): Sociedades de cultura, Sociedades de ciencia. Ensayos sobre la condición moderna, Oviedo, Nobel.

LASH, S. (1991): «Postmodernism as Humanism? Urban Space and Social Theory», en B. S. Turner (ed.), Theories of Modernity and Postmodernity, Londres, Sage.

- (1997): «La reflexividad y sus dobles: Estructura, estética y comunidad», en U. Beck, A. Giddens y S. Lash, Modernización reflexiva. Política, tradición y estética en el orden social moderno, Madrid, Alianza.

LUCKMANN, Th. (2000): “Comunicación moral e instituciones intermedias en las sociedades modernas», en Papers, n. ${ }^{\circ} 60$, pp. 83-96.

LYOTARD, J.-F. (1998): La condición posmoderna, Madrid, Cátedra.

MAFFESOLI, M. (1990): El tiempo de las trib us: el declive del individualismo en las sociedades de masas, Barcelona, Icaria. 
MARINAS, J. M. (2001): La fábula del bazar. Orígenes de la cultura del consumo, Madrid, Antonio Machado Libros.

MARIN, J. L. (1999): «The myth of the consumption-oriented economy and the rise of the desiring subject», en Theory and Society, n. ${ }^{\circ} 28, \mathrm{pp} .425-453$.

PICÓ, J. (1998): Modernidad y Postmodernidad, Madrid, Alianza.

PINO, J. del (1991): La teoría sociológica. Un marco de referencia analítico de la modernidad, Madrid, Tecnos.

PINO, J. del, y BERICAT, E. (1998): Valores sociales en la cultura andaluza, Madrid, CIS.

POSTER, M. (1988): Jean Baudrillard: Selected Writings, Cambridge, Polity Press.

RODRíGUEZ IBÁÑEZ, J. E. (1998): ¿Un nuevo malestar en la cultura? Variaciones sobre la crisis de la modernidad, Madrid, Centro de Investigaciones Sociológicas (CIS).

SCHEFF, Th. J. (1990): Microsociology. Discourse, Emotion and Social Structure, Chicago, The University of Chicago Press.

SEIDMAN, S., y WAGNER, D. G. (eds.) (1992): Postmodernism and Social Theory, Cambridge (MA), Blackwell.

SENNET, R. (1998): La corrosión del carácter. Las consecuencias personales del trabajo en el nuevo capitalismo, Barcelona, Anagrama.

SIMMEL, G. (1997): «The conflict of Modern Culture», en D. Frisby y Mike Featherstone (eds.), Simmel on Culture. Selected Writings, Londres, Sage.

SMART, B. (1997): Postmodernity, Londres, Routledge.

TOURAINE, A. (1969): La sociedad post-industrial, Barcelona, Ariel.

— (1995): Critique of Modernity, Oxford y Cambridge (MA), Blackwell.

TURNER, B. S. (ed.) (1991): Theories of Modernity and Postmodernity, Londres, Sage.

WEINSTEIN, D., y WENSTEIN, M. A. (1991): «Simmel and the theory of postmodern society», en B. S. Turner, Theories of Modernity and Postmodernity, Londres, Sage.

WELLMER, A. (1998): «La dialéctica de la modernidd y postmodernidad», en J. Picó, Modernidad y Postmodernidad, Madrid, Alianza. 
ABSTRACT

So huge is the amount of social, political, economical and cultural changes, which are taking place in advances societies, that many social scientists are wondering if we are confronting with a real epochal change. In answering that question, the article presents a set of theoretical works that describe and analyse contemporary social change. Although all these contributions highlight the importance of that changes, they also show an academic divide between «continuists» and «rupturists». The first ones think of changes as a continuing development of the modernization process. The second ones, on the contrary, think that we are entering on a new and post-modern era.

Even though we may believe that post-modernity, as a concept, is only an academic fashion among many others, or that it lacks of enough rigor to be useful to scientific purposes, we can use it as a very powerful lever to stimulate new kinds of observation and thinking. We do not know right now what post-modernity actually means, but we do know we need new ways of thinking to be able to understand this new world. So far we have only some fragments of this «posmodern» reality. This article presents some of them.

Finally, in this article we are offering a new approach based on the «posmodern bifurcation» hypothesis. According to this hypothesis, we see post-modernity as a double-faced process running simultaneously through two opposite paths. One leads us to higher grades of modernization, to a hypermodern stage of society. The other leads us to a restoration of traditional resources, to a revaluation of traditional societies. We demand more modernity, but we also demand to recuperate traditional values and structures. Posmodern people don not feel that Modern Society and Traditional Society oppose each other simply, rather they are trying to make new hybridisations taking from each kind of society whatever they feel may improve the quality of their lives. 